\title{
The changes in ENSO-induced tropical Pacific precipitation variability in the past warm and cold climates from the EC-Earth simulations
}

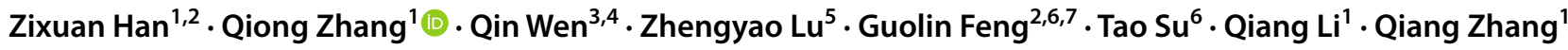

Received: 2 December 2019 / Accepted: 29 April 2020 / Published online: 21 May 2020

(c) The Author(s) 2020

\begin{abstract}
The El Niño-Southern Oscillation (ENSO) is one of the most significant climate variability signals. Studying the changes in ENSO-induced precipitation variability (ENSO precipitation) in the past climate offers a possibility to a better understanding of how they may change under future climate conditions. This study uses simulations performed with the European community Earth-System Model (EC-Earth) to investigate the relative contributions of dynamic effect (the circulation anomalies together with the climatological specific humidity) and thermodynamic effect (the specific humidity anomalies together with the climatological circulation) on the changes in ENSO precipitation in the past warm and cold climates, represented by the Pliocene and the Last Glacial Maximum (LGM), respectively. The results show that the changes in ENSO precipitation are intensified (weakened) over the tropical western Pacific but weakened (intensified) over the tropical central Pacific in Pliocene (LGM) compared with the pre-industrial (PI) simulation. Based on the decomposed moisture budget equation, these changes in ENSO precipitation patterns are highly related to the dynamic effect. The mechanism can be understood as follows: the zonal gradient of the mean sea surface temperature (SST) over the tropical Indo-Pacific is increased (reduced) during the Pliocene (LGM), leading to the strengthening (weakening) of Pacific Walker Circulation as well as a westward (eastward) shift. In the Pliocene, the westward shift of Walker Circulation results in an increased (decreased) ENSO-induced low-level vertical velocity variability in the tropical western Pacific (central Pacific), and, in turn, favoring convergent (divergent) moisture transport through a dynamic process, and then causing intensified (weakened) ENSO precipitation there. The opposite mechanism exists in LGM. These results suggest that changes in the zonal SST gradient over tropical Indo-Pacific under different climate conditions determine the changes in ENSO precipitation through a dynamic process.
\end{abstract}

Keywords El Niño-Southern Oscillation · Precipitation variability · The Pliocene · The Last Glacial Maximum · Dynamic and thermodynamic contribution $\cdot$ Zonal SST gradient $\cdot$ Walker circulation

Qiong Zhang

Qiong.zhang@natgeo.su.se

1 Department of Physical Geography and Bolin Centre for Climate Research, Stockholm University, Stockholm, Sweden

2 College of Atmospheric Sciences, Lanzhou University, Lanzhou, China

3 Laboratory for Climate and Ocean-Atmosphere Studies (LaCOAS) and Department of Atmospheric and Oceanic Sciences, School of Physics, Peking University, Beijing, China
4 Department of Meteorology (MISU), Stockholm University, Stockholm, Sweden

5 Department of Physical Geography and Ecosystem Science, Lund University, Lund, Sweden

6 College of Physical Science and Technology, Yangzhou University, Yangzhou, China

7 Laboratory for Climate Studies, National Climate Center, China Meteorological Administration, Beijing, China 


\section{Introduction}

El Niño-Southern Oscillation (ENSO), developed through atmosphere-ocean interactions in the tropical Pacific Ocean, is one of the strongest climate variabilities on interannual timescales (McPhaden et al. 2006; Collins 2010). The large regional precipitation anomalies associated with the evolution of ENSO have been extensively studied (e.g., Kiladis and Diaz 1989; Vecchi and Wittenberg 2010; Huang and Xie 2015; Lu et al. 2016). Zhou et al. (2014) indicate that the ENSO-induced teleconnections shift eastward over North America and North Pacific in a warmer climate. Bonfifils et al. (2015) illustrate that these anomalous teleconnections are owing to the eastward movement of ENSO-driven precipitation variability (ENSO precipitation). Note that the ENSO-driven large-scale atmospheric teleconnections can not only lead to considerable damages to economies, agriculture, and ecosystems, but also cause severe climatic disasters worldwide (Philander 1990; McPhaden et al. 2006; Deser et al. 2010).

Recent studies suggest that the changes in ENSO precipitation may be large under global warming, even if the sea surface temperature (SST) and sea level pressure (SLP) changes remain uncertain (Seager et al. 2012; Chung et al. 2014; Cai 2015). That is, the changes in ENSO precipitation are projected to increase over the equatorial Pacific in phases 3 and 5 of the Coupled Model Intercomparison Project (CMIP3 and CMIP5). Specifically, Power et al. (2013) demonstrate that the projected ENSO precipitation will be reduced (increased) over western (central-eastern) Pacific in the future warmer climate. They suggest that the nonlinear response of atmospheric circulation to surface warming plays a crucial role. Huang and Xie (2015) further study the nonlinear process of changes in ENSO precipitation in CMIP5 data by using the moisture budget decomposition method. They show that both dynamic (reflected by the changes in circulation) and thermodynamic (reflected by the changes in specific humidity) components contribute to the changes in the ENSO precipitation pattern. Besides, Huang (2016) finds that the enhanced ENSO precipitation shifts eastward steadily under global warming. This eastward shift is related to the circulation anomalies in response to global warming (Seager et al. 2012; Chung et al. 2014; Chung and Power 2014). Most previous studies predict a weakening and eastward shift of the Walker Circulation under global warming (Vecchi et al. 2006; Vecchi and Soden 2007; Power and Kociuba 2011; Bayr et al. 2014) because of the decreased zonal SST gradient over tropics (Ma and Xie 2012; He and Soden 2015), which plays a crucial role in changes in precipitation in tropics and subtropics.

While considerable efforts have been devoted to examining the changes in the ENSO precipitation under current global warming, less attention has been given to exploring the changes in ENSO precipitation in the past climate. The ENSO precipitation changes under different climate conditions can help us to understand the underlying mechanisms and provide the validation of future climate simulations. Reconstructions show that the Pliocene (3.264 to 3.025 million years before present day) is the most recent period in the past with atmospheric $\mathrm{CO}_{2}$ concentration similar to the anthropogenically forced levels seen present-day (Raymo et al. 1996; Dowsett et al. 2012; Fedorov et al. 2013; Herbert et al. 2016; Martínez et al. 2015) and the continental configuration is similar to the modern climate (Dowsett 2007). The global temperatures are $2-3{ }^{\circ} \mathrm{C}$ warmer than that in the present (Ravelo et al. 2004; Dowsett and Robinson 2009). This period is regarded as a potential analog to future climate scenario (Robinson et al. 2008). Reconstructions of SST from $\mathrm{Mg} / \mathrm{Ca}$ paleothermometry and $\delta^{18} \mathrm{O}$ records suggest that the zonal SST gradient is reduced over the tropical Pacific during this period (Wara et al. 2005; Dekens et al. 2007). However, Rickaby and Halloran (2005) provide strong evidence that the eastern equatorial Pacific has a $\mathrm{La}$ Nina-like state by the Pliocene paleothermometer, leading to an increase in the zonal SST gradient in tropics. Therefore, there is much debate for the ENSO characteristics since it has been found a "permanent El Niño" in the tropical Pacific (Molnar and Cane 2002; Fedorov et al. 2006; Scroxton et al. 2011; Watanabe et al. 2011) or with variability (Haywood et al. 2007; Bonham et al. 2009; Jochum et al. 2009; Galeotti et al. 2010; Von der Heydt et al. 2011).

Another cold period in the past, the Last Glacial Maximum (LGM, $\sim 21 \mathrm{Ka} \mathrm{BP}$ ), is the most recent glacial interval with $\mathrm{CO}_{2}$ concentration around $180 \mathrm{ppm}$, with global mean temperature is about $5{ }^{\circ} \mathrm{C}$ colder than the present-day (Clark et al. 2009). The evidence for ENSO variability during LGM still exists a substantial discrepancy in the paleoclimate records. Some oxygen isotope reconstructions indicate a weaker ENSO than that of the pre-industrial (PI) (Leduc et al. 2009), while others suggest a stronger ENSO (Koutavas and Joanides 2012; Sadekov et al. 2013). Some climate modelling studies suggest a stronger ENSO variability with a weakened zonal SST gradient in tropics (Otto-Bliesner et al. 2003; An et al. 2004), some suggest the occurrence of opposite situation (Peltier 2004). These limitations by only considering cold or warm climate motivate this study to systematically investigate ENSO variations and their impacts on the largescale hydrological cycle in both past warm and cold climates.

In this paper, two experiments with different past periods, i.e. Pliocene and LGM are compared with the reference of the PI simulation using the European community Earth-System Model EC-Earth. We focus on the response of ENSO precipitation in these two climate periods. Because the precipitation anomaly is highly associated with the processes involved in the atmospheric moisture budget, and the changes in moisture content are mainly driven by the anomalous dynamic 
and thermodynamic impacts (Seager et al. 2010; Seager and Vecchi 2010; Huang and Xie 2015; Han et al. 2019). Thus, we further examine the linearized moisture budget components to investigate the potential mechanisms of precipitation changes in response to past warm and cold conditions. The paper is structured as follows. The EC-Earth model and experimental design are briefly described in Sect. 2. In Sect. 3, we present the changes in simulated ENSO precipitation based on the moisture budget analysis. The corresponding physical mechanisms are discussed in Sect. 4. The conclusions and discussion are summarized in Sect. 5.

\section{Model and methods}

\subsection{Model description and experimental design}

We use the global coupled climate model EC-Earth 3.1 (Hazeleger et al. 2012) in this study. The atmospheric component is the Integrated Forecast System (IFS, version cycle 36r4) of the European Centre for Medium-Range Weather Forecasts (ECMWF), which includes the land model H-TESSEL (Balsamo et al. 2009). The IFS is run at T159 horizontal resolution, approximately equivalent to a $125 \mathrm{~km}$ (or $\sim 1.125^{\circ}$ ), and there are 62 vertical levels. The atmospheric model is coupled to the ocean component according to the Nucleus for European Modelling of the Ocean (NEMO, version 3.3, Madec 2008) and the version 3 of the Louvain-la-Neuve sea-ice Model LIM3 (Vancoppenolle et al. 2009). The resolution for NEMO is about $1^{\circ}$ and 46 vertical levels. The Ocean-Atmosphere Sea Ice Soil coupler (version 3.0) OASIS3 (Valcke 2006) is used to couple the atmosphere, land and ocean/sea ice. EC-Earth is widely used to explore the past, present and future climate change, e.g. the Arctic amplification during mid-Pliocene (Zheng et al. 2019), the Northern Hemisphere land monsoon precipitation during the mid-Holocene (Sun et al. 2019). ECEarth also contribute to the Fifth Assessment Report of the Intergovernmental Panel on Climate Change (IPCC AR5) (Hazeleger et al. 2012; Collins et al. 2013; Flato et al. 2013) and the Paleoclimate Modelling Intercomparison Project Phase3 (PMIP3) (Bosmans et al. 2012). The model simulates ENSO variability reasonably well (Sterl et al. 2012; Hazeleger et al. 2010), the ENSO related atmospheric circulation, such as the Walker circulation changes, is correctly represented during mid-Holocene (Pausata et al. 2017). In the current study, we apply this model to examine the Pliocene and LGM climates, focusing on the ENSO-driven variability of precipitation over tropics as well as the corresponding mechanisms.

Three simulation data with EC-Earth 3.1 are analysied. One is the PI experiment with the $\mathrm{CO}_{2}$ level as $284.725 \mathrm{ppm}$, used as the control simulation. Another one is the Pliocene in which the $\mathrm{CO}_{2}$ level is set to $400 \mathrm{ppm}$. The Pliocene simulation follows the protocol of the Pliocene Model Intercomparison Project phase 2 (PlioMIP2, Haywood et al. 2016). In this simulation, other trace gases, $\mathrm{N}_{2} \mathrm{O}$ and $\mathrm{CH}_{4}$, and aerosols are set the same as in PI run. And the boundary conditions are provided by the Interpretation and Synoptic Mapping group (Dowsett et al. 2016), include the orography, landsea mask, ice-sheet, soil, vegetation, and bathymetry. The orbital forcing is the same as the PI run. The third one is the Last Glacial Maximum (LGM) experiment, which follows the Paleoclimate Modelling Intercomparison Project Phase 3 (PMIP3) protocol. The concentration of trace gases $\mathrm{CO}_{2}$, $\mathrm{N}_{2} \mathrm{O}$ and $\mathrm{CH}_{4}$ are set to $185 \mathrm{ppm}, 200 \mathrm{ppb}$, and $350 \mathrm{ppb}$, respectively. The orbital parameters of obliquity, eccentricity, and longitude of perihelion are set to $22.949^{\circ}, 0.018994$, and $180^{\circ}+114.42^{\circ}$, respectively. The boundary conditions, e.g. the ice sheet cover, the topography (land-sea mask and the change of the surface elevation data), and bathymetry, are following the PMIP3 protocol (https://pmip3.1sce.ipsl. fr). The initial condition for Pliocene is from the PI control, and the initial condition for LGM is from a cold ocean state from Zhang et al. (2013). In this study, all experiments are integrated for another 300 years after the equilibrium, and the data from last 100 years are post-processed for analysis.

The monthly mean SST and precipitation data from the Met Office HadISST version 1.1 (Rayner et al. 2003), with a spatial resolution of $1^{\circ} \times 1^{\circ}$ from 1901 to 2000 . In addition, the precipitation is from Global Precipitation Climatology Project (GPCP) Version 2.3 (Adler et al. 2003), with a spatial resolution of $2.5^{\circ} \times 2.5^{\circ}$ from 1979 to 2000 .

\subsection{Moisture budget decomposition}

According to the decomposed moisture budget equation, the changes in precipitation $(\delta \mathrm{P})$ are mainly dominated by the mean circulation dynamic $(\delta M C D)$, thermodynamic $(\delta T H)$, evaporation $(\delta \mathrm{E})$ and transient eddy convergence terms

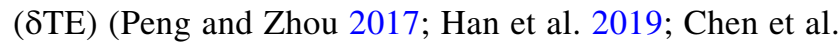
2019). Here, we use the simplified method to decompose the moisture budget terms that is described in details by Seager et al. (2012),

$$
\delta \bar{P} \approx \delta \bar{E}-\underbrace{\delta \frac{1}{\rho_{w} g} \int_{0}^{\bar{p}_{s}}\left[\nabla \cdot\left(\overline{\bar{u}}_{T} \hat{q}_{T}\right)\right] d p}_{\delta T H} \underbrace{-\delta \frac{1}{\rho_{w} g} \int_{0}^{\bar{p}_{s}}\left[\nabla \cdot\left(\hat{u}_{T} \overline{\bar{q}}_{T}\right)\right] d p}_{\delta M C D} \underbrace{-\delta \frac{1}{\rho_{w} g} \int_{0}^{\bar{p}_{s}}\left[\nabla \cdot\left(\overline{u^{\prime} q^{\prime}}\right)_{T}\right] d p}_{\delta T E} .
$$


where $\rho_{\mathrm{w}}$ is the water density, $\boldsymbol{u}$ is the horizontal wind and $q$ is the specific humidity. The single overbars represent the monthly means, the double overbars indicate the climatological means. The hat represents the monthly variables departure from the climatological monthly mean, and the primes indicate the variables departure from the monthly means. Note that the $E, P, \boldsymbol{u}$, and $q$ are directly derived from model output, whereas $\delta$ TE is calculated by the difference between $\delta \mathrm{P}$ and the sum of the $\delta \mathrm{E}, \delta \mathrm{TH}$ and $\delta \mathrm{MCD}$ terms. In this study, the difference $\delta$ is represented by

$\delta(\cdot)=[\cdot]_{E l}-[\cdot]_{L a}$

where the subscripts $\mathrm{El}$ and La refer to the time averaging of variables over months with El Niño or La Niña events. We use the empirical orthogonal function (EOF) analysis of the monthly SST anomaly (SSTA) over tropical Pacific $\left(120^{\circ} \mathrm{E}-80^{\circ} \mathrm{W} ; 20^{\circ} \mathrm{S}-20^{\circ} \mathrm{N}\right)$ to extract the ENSO pattern in each experiment, after remove the long-term trends. We define El Niño (La Niña) months when PC1 exceeds (below) one standard deviation. In this study, the ENSO-induced variability, e.g. ENSO-driven SST variability (ENSO SST), ENSO-driven precipitation (ENSO precipitation), is determined by calculating the differences of SST and other variables (e.g. precipitation, circulation, vertical velocity) between composites in El Niño and La Niña months. And the changes in ENSO variables are determined by the differences between ENSO variables in Pliocene or LGM simulation compare with ENSO variables in PI.

The changes in ENSO precipitation can be further decomposed in several components as follows:

$\Delta[\delta \bar{P}] \approx \Delta[\delta \bar{E}]+\Delta[\delta T H]+\Delta[\delta M C D]+\Delta[\delta T E]$.

where $\Delta[\bullet]$ represents the difference of variables between the sensitivity experiments and the control experiment.

\section{Results}

\subsection{Changes in ENSO variability}

We first use the EOF analysis on SST to extract the ENSO pattern (see Sect. 2.2). Figure 1 shows the spatial patterns of the leading EOF mode of SST in HadISST and model simulations. The total variance for the PI, Pliocene, and
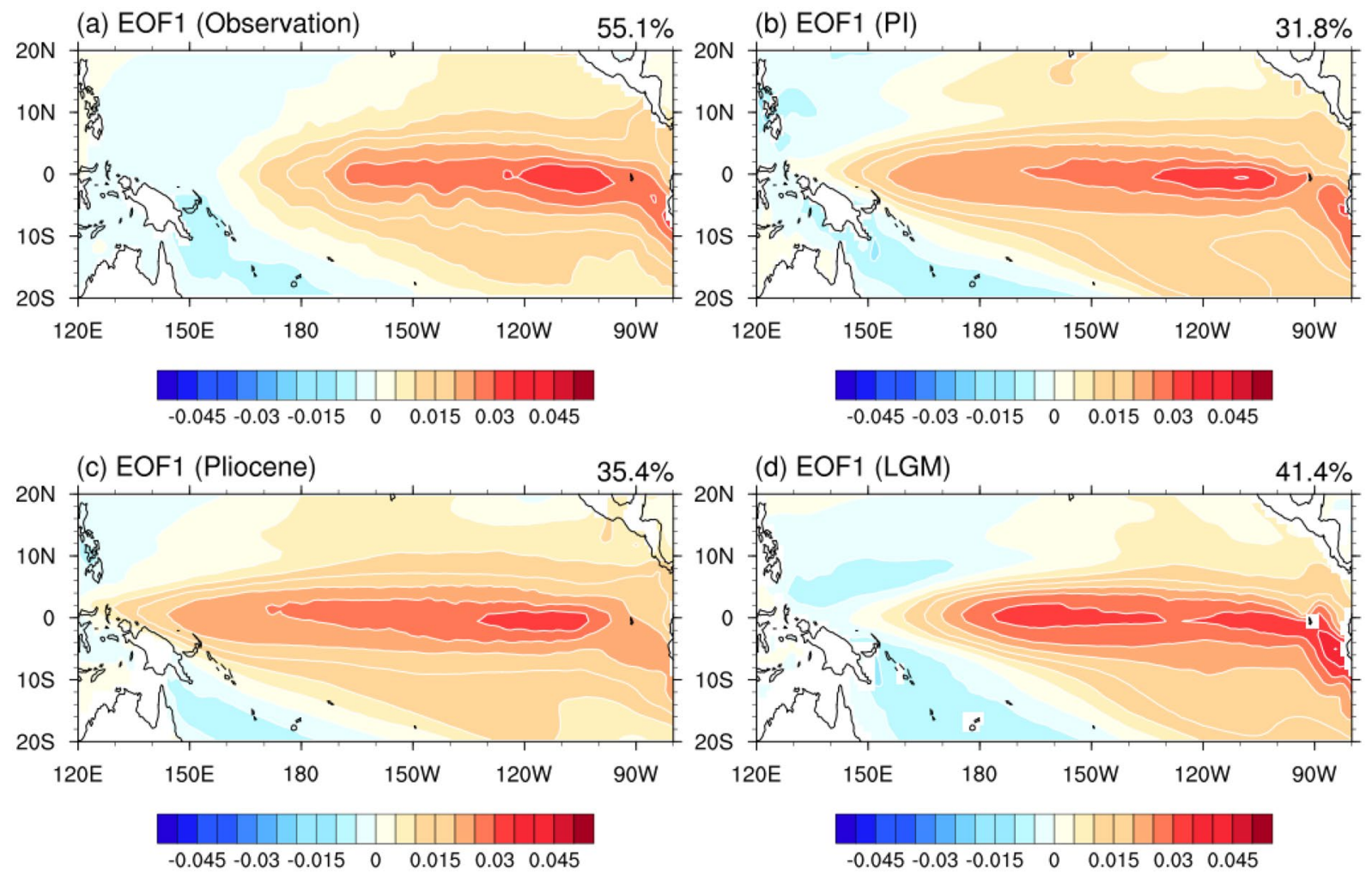

Fig. 1 Spatial patterns of the leading EOF mode for monthly SST anomaly (SSTa) over the tropical Pacific Ocean $\left(120^{\circ} \mathrm{E}-80^{\circ} \mathrm{W}\right.$, $\left.20^{\circ} \mathrm{S}-20^{\circ} \mathrm{N}\right)$. The SST derived from Met Office HadISST (a), PI (b), Pliocene (c) and LGM (d) simulation. Before using the EOF, the

SSTa are detrended to remove the long-term trends. The corresponding percentages of explained variances are given in the upper right corner. Units: ${ }^{\circ} \mathrm{C}$ 
LGM are $31.8 \%, 35.4 \%$, and $41.4 \%$, respectively, and these are smaller than the results of observational SST $(55.1 \%)$. In the HadISST, the warm SSTs occur in broad equatorial central-east Pacific, extending northward along the North American coastal region, and contrast with a cold SST in the "horseshoe" pattern in the western Pacific (Fig. 1a). In addition, the corresponding time series of EOF1 show obvious interannual variability (Fig. 2a-d). According to the definition in Sect. 2.2, there are 190 (194) El Niño (La Niña) months in HadISST during 1901-2000. In ECEarth 100-year simulation for PI, Pliocene and LGM, there are 174 (189) in PI, 189 (190) in Pliocene and 157 (175) in LGM, respectively. The EC-Earth simulations well capture the spatial distribution of ENSO variability (Fig. 1b-d), except that the warm SST areas extend too far to the west compared to HadISST (Hazeleger et al. 2012; Pausata et al. 2017). This bias is also shown in other model simulations (Vecchi and Wittenberg 2010; Capotondi et al. 2015). Power et al. (2013) demonstrate that the changes in ENSO precipitation are mainly caused by a nonlinear response to robust changes in background SST due to climate conditions (e.g. global warming), and unchanged ENSO SST in 21 s century, but not uncertain changes in ENSO SST. Previous studies (e.g. Huang and Xie 2015; Huang 2016) suggest that this kind of bias does not influence the discussion of the changes in ENSO precipitation. The power spectral of PC1 of the SST observation shows that the dominant period of ENSO is around 2-6 years, which is captured by our PI simulation. The reasonable agreement of PC1 of the tropical Pacific SST between observation and simulation suggests that the EC-Earth model can well reproduce the ENSO periodicity. Note that the ENSO period does not change much in the three sensitivity simulations (Fig. 2e).
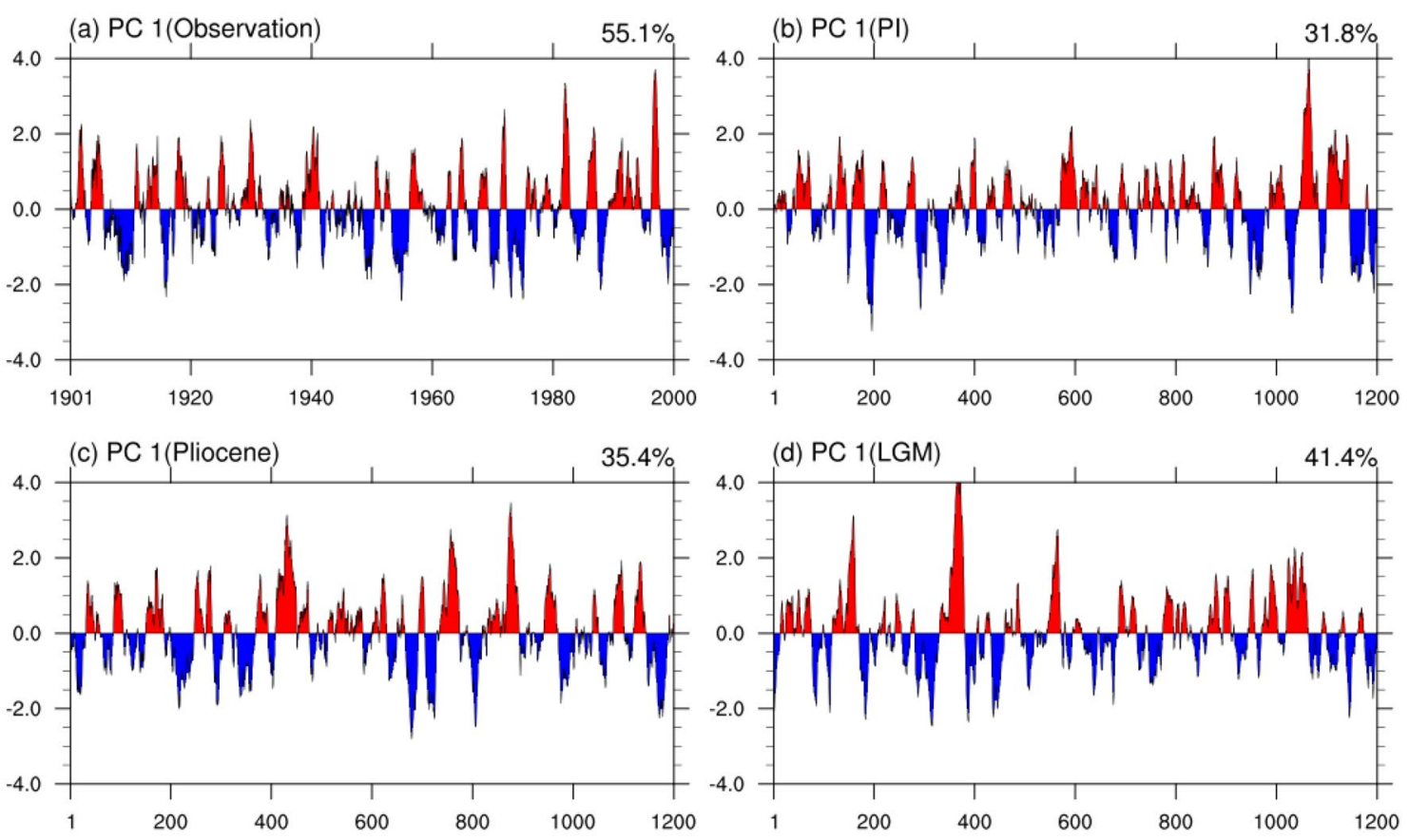

(d) PC 1(LGM)
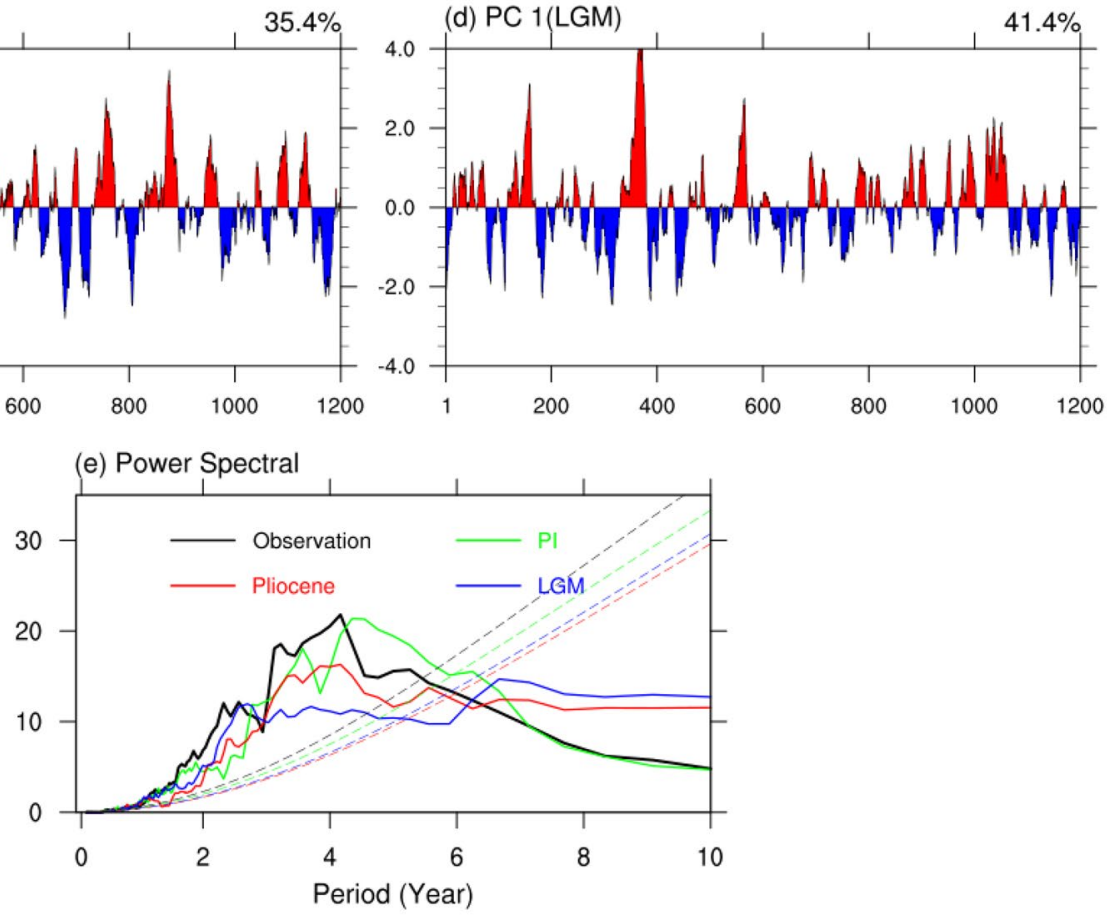

Fig. 2 The normalized time series of EOF 1 for a HadISST during 1901-2000, b PI, c Pliocene and d LGM simulations. e The power spectrum of the PC1s, with $95 \%$ confidence levels (dashed lines). The PC1s are first smoothed with a 5-85 month band-pass filter 


\subsection{Changes in ENSO precipitation in past warm and cold climate}

Figure $3 \mathrm{~b}$ shows that the ENSO precipitation pattern in the PI simulation is positive across the tropical Pacific, and negative along the northern edge of the intertropical convergence zone (ITCZ), with the maximum value located around $155^{\circ} \mathrm{E}$. A similar pattern is also found in Pliocene and LGM (Figures not shown). The positive ENSO precipitation is understood as the response to the warming SST. Relative to La Niña, during the El Niño events, due to the weakened easterlies, the upwelling over the east Pacific decreases through the ocean-atmosphere interactions, inducing further warming over the tropical eastern Pacific. And the reduced zonal SST gradient further decreases the easterlies, resulting in the Bjerknes feedback (Bjerknes 1969). The anomalous warm water appears in the central and eastern equatorial Pacific (Fig. 1a), inducing the convergence zone over the Maritime continent to migrate eastward (Cai et al. 2010). The ENSO precipitation is sensitive to an eastward shift of the convection center, resulting from the weakened and eastward movement of the Walker Circulation (Dai and Wigley 2000). The reduced ENSO precipitation along the northern edge of the ITCZ might be caused by the equatorward shift of ITCZ over the tropical eastern Pacific (Rasmusson and Carpenter 1982). Compare to the observation, the ENSO precipitation in our simulation is apparently located farther west (Fig. 3a, b), which is caused by the west extent of warm SST over the tropical Pacific (Fig. 1b-d). Compared to PI, the most striking features in Pliocene are enhanced ENSO precipitation over the western Pacific with the maximum value at around $120^{\circ} \mathrm{E}-150^{\circ} \mathrm{E}$ but weakened over the central Pacific and no obvious changes in eastern Pacific (Fig. 3b). A roughly opposite phenomenon occurs in LGM, with weakened ENSO precipitation over the western Pacific but enhanced ENSO precipitation over the central Pacific (Fig. 3c). In addition, we observe larger precipitation variability in winter over the tropical Pacific Ocean where ENSO originates (not shown). Results indicate that the changes in the tropical Pacific precipitation variability are dominated by the anomalies in wintertime (not shown).

The major forcing in the two sensitivity experiments for Pliocene and LGM is the $\mathrm{CO}_{2}$ level, one with higher $\mathrm{CO}_{2}$ and one is lower. These forcings result in the opposite changes in some regions but the similar changes in another region in ENSO precipitation, indicating the physical mechanism might be different when increase or decrease the $\mathrm{CO}_{2}$ forcing. Below we further investigate which factor is the major contributor to the changes in ENSO precipitation by analyzing the moisture budget decomposition.

\subsection{Changes in dynamic and thermodynamic mechanisms}

Figure 4a-d shows the decomposed moisture budget components of the ENSO precipitation for PI simulation according to Eq. (1). Here, we calculate the pattern correlation coefficient (PCC), which means the coefficient of linear (a) ENSO precipitation (Observation)

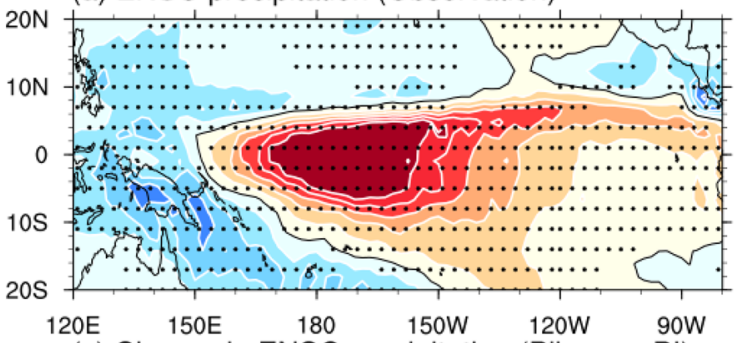

(c) Change in ENSO precipitation (Pliocene-PI)

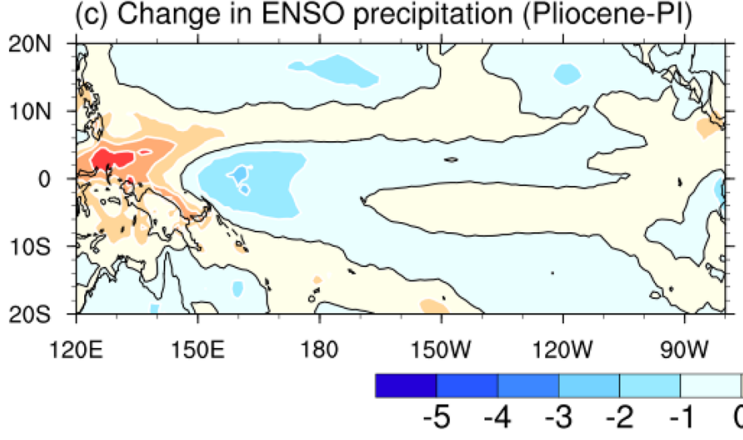

Fig. 3 The ENSO precipitation in a GPCP observation, b PI simulation, and changes in ENSO precipitation during $\mathbf{b}$ Pliocene and $\mathbf{c}$ LGM simulations compared to PI (unit: $\mathrm{mm} \mathrm{day}^{-1}$ ). The solid black (b) ENSO precipitation (PI)

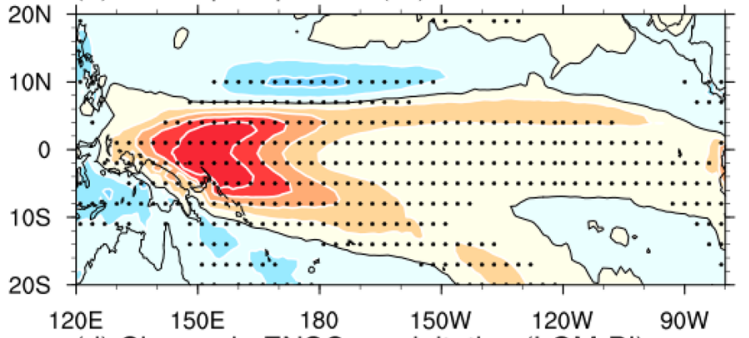

(d) Change in ENSO precipitation (LGM-PI)

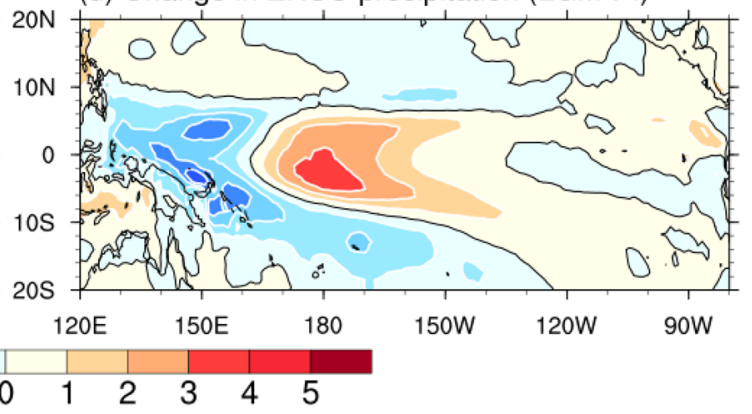

contours represent zero lines. The stippling in $\mathbf{a}, \mathbf{b}$ indicates a statistical significance at $95 \%$ level by using the Mann-Kendall trend test 

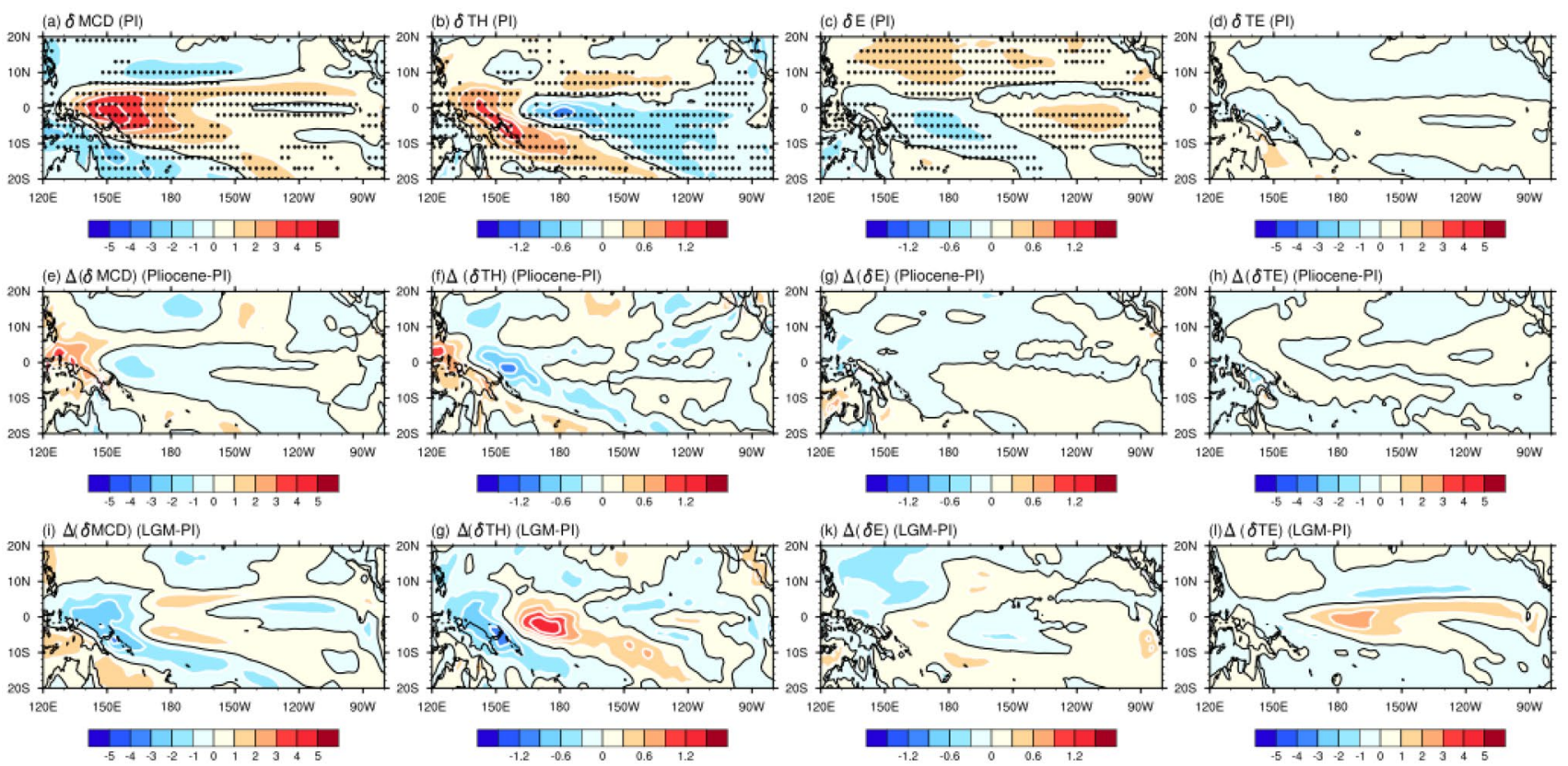

Fig. 4 a The dynamic, $\mathbf{b}$ thermodynamic, $\mathbf{c}$ evaporation and $\mathbf{d}$ transient eddy convergence components in PI simulation (unit: $\mathrm{mm}$ $\left(d a y^{-1}\right)$. The corresponding changes in $\mathbf{e}-\mathbf{h}$ and $\mathbf{i}-\mathbf{l}$ are moisture budget components for Pliocene and LGM, respectively. The solid black curves represent zero lines. The stippling indicates a statistical significance at the $95 \%$ level by using the Mann-Kendall trend test correlation between two variables on two different maps, and here, the positive (negative) values indicate the same (opposite) anomaly between two variables. The mean circulation dynamic $\delta M C D$ term (Fig. 4a) exhibit a similar pattern and amplitude to the ENSO precipitation (Fig. 1a) with a PCC of 0.93. Compared with the $\delta \mathrm{MCD}$ term, the contribution from the thermodynamic $\delta \mathrm{TH}$ to ENSO precipitation is much less with PCC of -0.3 , showing a slightly enhanced (weakened) precipitation over the western (central-eastern) Pacific. These changes are consistent with the results of Seager et al. (2012). This physical process can be modulated through the Clausius-Clapeyron relationship linked to the near-surface temperature changes (Held and Soden 2006). In equatorial Pacific cold tongue, there are mean low-level divergent winds, i.e. $\nabla \cdot \overline{\bar{u}}>0$. During the El Niño (La Niña), the anomalous positive (negative) specific humidity, i.e., $\hat{q}>0(\hat{q}<0)$, occurs in this region caused by the positive (negative) SST anomalies. These two factors lead to a negative thermodynamic effect, i.e. $-\delta \frac{1}{\rho_{w} g} \int_{0}^{\bar{p}_{s}}[\overline{\bar{u}} \hat{q}] d p<0$. As the mean low-level winds show convergence over the western Pacific, i.e., $\nabla \cdot \overline{\bar{u}}>0, \underline{\delta} \mathrm{TH}$ contribution shows a positive effect, i.e. $-\delta \frac{1}{\rho_{w} g} \int_{0}^{\bar{p}_{s}}[\overline{\bar{u}} \hat{q}] d p>0$. These features favor more ENSO precipitation over tropical western Pacific and less ENSO precipitation over tropical eastern Pacific, leading to an increase and offset the $\delta \mathrm{MCD}$ contribution, respectively. The $\delta \mathrm{E}$ in Fig. $3 \mathrm{c}$ shows the least contribution to ENSO precipitation, leading to decreased (increased) precipitation over western (eastern) Pacific. The transient eddy convergence term $\delta$ TE (Fig. 3d) mainly reflects the storm tracks located in the mid-to-high latitudes (Seager et al. 2014; Chang et al. 2002). Therefore, $\delta$ TE shows a relatively weaker impact on the ENSO precipitation especially compared to the first-order contribution term (SMCD) over the tropical Pacific.

Thus, the first-order changes in ENSO precipitation are a consequence of the change in circulation together with the climatological humidity ( $\mathrm{MMCD}$ term). The same results are also shown in the other two sensitive experiments (figure not shown) despite the different climate forcing. The changes in moisture budget components in sensitivity simulations compared to the PI simulation are shown in Fig. 4e-1. For the Pliocene and LGM, the changes in ENSO precipitation (Fig. 3b, c) are mainly contributed by the changes in dynamic process $\delta \mathrm{MCD}$, with the PCCs of 0.86 and 0.76 for Pliocene and LGM, respectively (Fig. 4e, i). The thermodynamic term $\delta \mathrm{TH}$ (Fig. 4f, g) plays a secondary role, with the PCCs of 0.44 and 0.58 for Pliocene and LGM, respectively. Comparing to these two terms, other terms ( $\delta \mathrm{E}$ and $\delta \mathrm{TE})$ are very small and can be neglected (Fig. 4g, h, k, 1).

In general, the ENSO precipitation changes during Pliocene and LGM are mainly controlled by the dynamic term $\delta \mathrm{MCD}$, and the second contribution comes from the $\delta \mathrm{TH}$ term, which is shown in Fig. 5. The changes in $\delta M C D$ explain the largest portion of precipitation anomalies over the western and central Pacific under different climate 

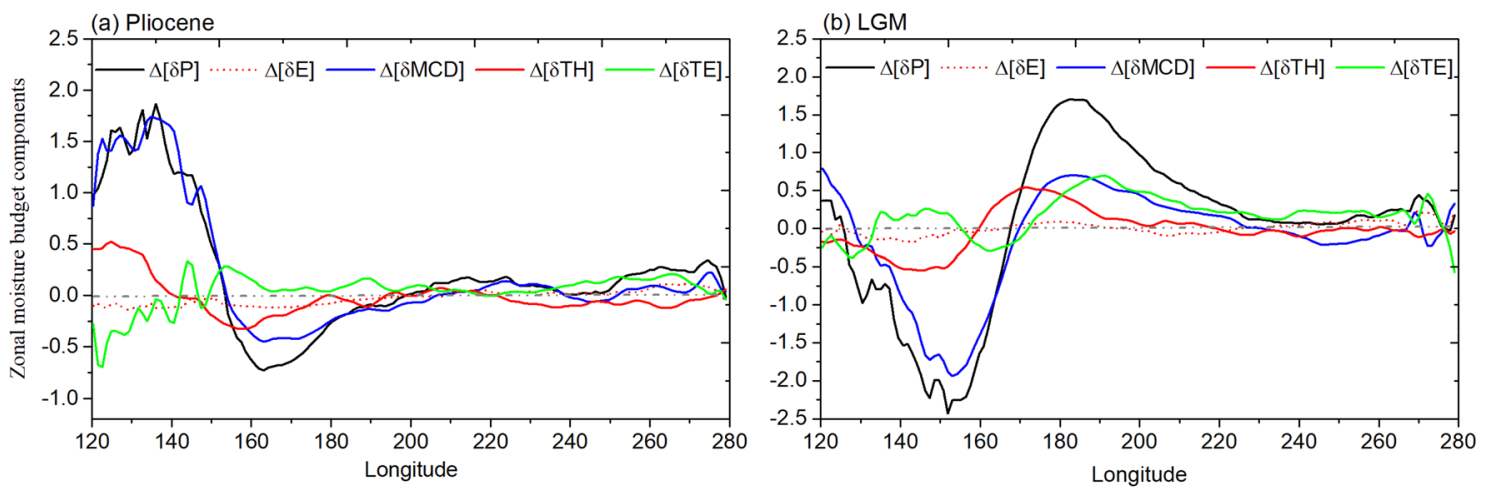

Fig. 5 The zonal mean of moisture budget components during a Pliocene and $\mathbf{b}$ LGM over tropical Pacific $\left(10^{\circ} \mathrm{S}-10^{\circ} \mathrm{N}\right)$

conditions. Relatively, the meridional mean of the change in $\delta \mathrm{TH}$ is much smaller than the change in $\mathrm{SMCD}$. The $\delta \mathrm{E}$ term even shows the opposite contribution to ENSO precipitation. This might because the change in ocean evaporation is not only influenced by temperature, but also other variables, i.e. the near-surface wind, the humidity gradient between the ocean and near-surface atmospheric, and the atmospheric stability (Liu et al. 1979; Yu 2007). All of these make the change in ocean evaporation more complex.

The $\delta$ MCD contribution can be further broken down into two terms (Seager et al. 2012),

$\Delta(\delta M C D) \approx \underbrace{-\delta \frac{1}{\rho_{w} g} \int_{0}^{\bar{p}_{s}} \nabla \cdot\left(\Delta \hat{u} \overline{\bar{q}}_{P I}\right) d p}_{\Delta\left(\delta M C D_{u}\right)} \underbrace{-\delta \frac{1}{\rho_{w} g} \int_{0}^{\bar{p}_{s}} \nabla \cdot\left(\hat{u}_{P I} \Delta \overline{\bar{q}}\right) d p .}_{\Delta\left(\delta M C D_{q}\right)}$

The first term on the right-hand side is caused by the change in circulation variability $(\Delta \hat{u})$ but no changed mean humidity $\left(\overline{\bar{q}}_{P I}\right)$. The second term is caused by the change in mean specific humidity $(\Delta \overline{\bar{q}})$ but no changed circulation variability. The subscripts PI refer to the time averaging of variables over months in the PI simulation.

Figure 6 shows the changes in these two terms. The second term, which reflects the impact of mean specific humidity anomaly (Fig. 6b, d) simply acts to increase (decrease) the changes in ENSO precipitation along the entire equatorial Pacific in Pliocene (LGM). This is not surprising because the Pliocene (LGM) is warmer (colder) than PI (Fig. 10a, c) and favors to increase (decrease) humidity in the atmosphere. Combined with the anomalous circulation $(\widehat{u})$, it shows the positive (negative) contribution to the changes in dynamic component $\delta M C D$ in Pliocene (LGM) (Fig. 6b, d). The first term $\Delta\left(\delta M C D_{u}\right)$, which reflects the changes in ENSO-driven circulation variability, shows the positive (negative) contribution over the western Pacific to increase (reduce) the changes in
ENSO precipitation, but negative (positive) contribution over the central Pacific to reduce (increase) the changes in ENSO precipitation during Pliocene (LGM). This pattern is similar to the $\delta$ MCD pattern (Fig. 4e, i) over the tropical Pacific, with the PCCs of 0.84 and 0.83 during Pliocene and LGM, respectively. That suggests that the anomalous circulation dominates the changes in ENSO precipitation both in Pliocene and LGM. Thus, based on the moisture budget decomposition, the opposite patterns of changes in ENSO precipitation in Pliocene and LGM mainly results from the dynamic effect (circulation anomalies) rather than the thermodynamic effect (specific humidity anomalies).

\subsection{Changes in ENSO-driven vertical velocity variability}

As discussed above, the changes in ENSO precipitation is mainly driven by the term that reflects the circulation anomalies combined with unchanged specific humidity for Pliocene and LGM. According to previous studies (Seager et al. 2012; Peng and Zhou 2017; Han et al. 2019), the dynamical term is highly related to the changes in vertical motion at the low-level atmosphere, which induces anomalous horizontal moisture divergence/convergence.

Figure 7a shows the ENSO-driven vertical velocity variability for the PI simulation, which resembles the observed patterns (Seager et al. 2012; Adames and Wallace 2017). During the El Niño events, there is pronounced ascending anomaly along the equatorial Pacific Ocean compared with that in La Niña, with a descending anomaly in the ITCZ to the south Pacific convergence zone (SPCZ). These patterns are similar to ENSO precipitation in Fig. 3b, suggesting the importance of the vertical motion at low-level troposphere in determining the precipitation anomaly. The changes in vertical velocity variability during Pliocene show increased amplitude over the Maritime Continent but reduced over the central Pacific with a negative center at about $160^{\circ} \mathrm{E}$. The opposite features occur in LGM simulation, showing the 
(a) $\triangle\left(\delta \mathrm{MCD}_{\mathrm{u}}\right)$ (Pliocene-PI)

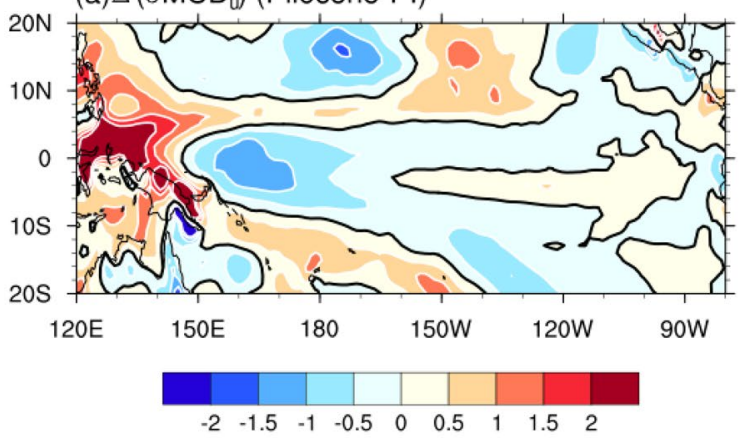

(c) $\Delta\left(\delta \mathrm{MCD}_{\mathrm{u}}\right)(\mathrm{LGM}-\mathrm{PI})$

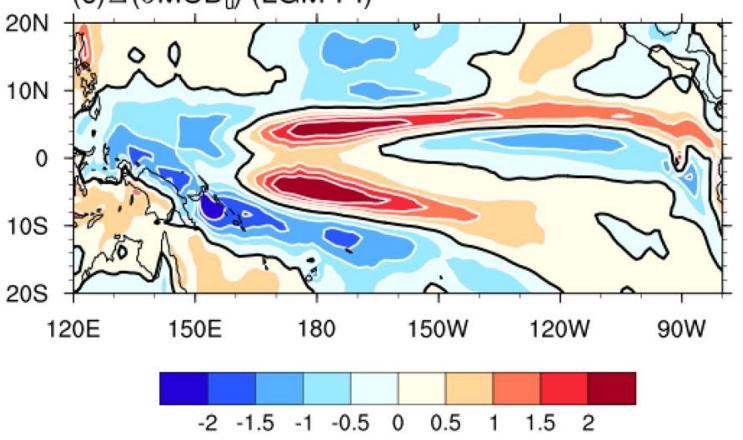

(b) $\triangle\left(\delta \mathrm{MCD}_{\mathrm{q}}\right)($ Pliocene-PI)

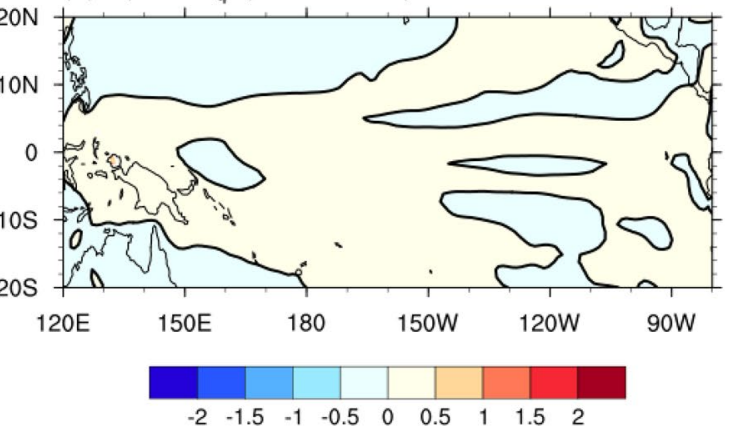

(d) $\Delta\left(\delta \mathrm{MCD}_{\alpha}\right)(\mathrm{LGM}-\mathrm{PI})$

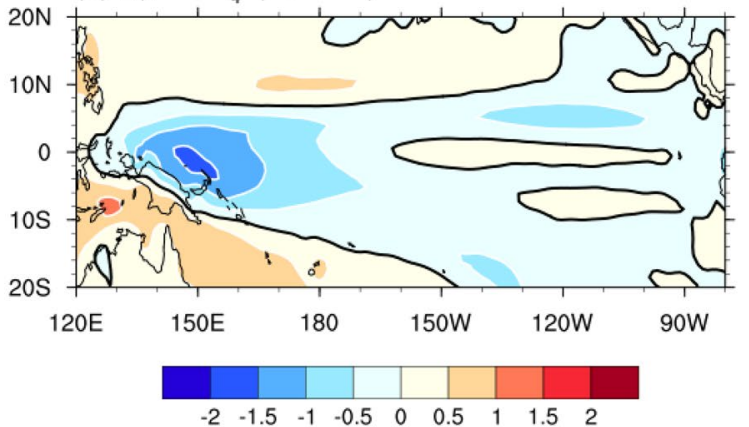

Fig. 6 The contribution of the change in $\delta M C D$ linked to the changes in circulation variability (left), and mean specific humidity (right) for Pliocene in $\mathbf{a}, \mathbf{b}$ and LGM in $\mathbf{c}, \mathbf{d}$. The solid black curves represent zero lines

weakened vertical motion variability in SPCZ, but enhanced variability in the central Pacific with a positive center at around $180^{\circ}$. The spatial distribution of changes in ENSO vertical velocity is highly similar to that of the $\triangle\left(\delta M C D_{u}\right)$ term (Fig. 6a, c), suggesting that the latter is tightly driven by the former.

\subsection{Changes in ENSO-driven Walker circulation variability}

A question arises as to which factor affects the vertical velocity anomaly at the low-level atmosphere during the past warm and cold periods. The corresponding changes in ENSO vertical velocity in Fig. 6 feature the westward (eastward) shift in Pliocene (LGM) compared with PI simulation, which implies the linkage to the changes in Walker Circulation (Tokinaga et al. 2012; Shi et al. 2018). Therefore, we apply the zonal mass stream function (ZMS) to analyze the changes in Walker Circulation (Yu et al. 2012; Schwendike et al. 2014; Bayr et al. 2014).

Figure 8 is the climate mean ZMS along the tropical IndoPacific $\left(10^{\circ} \mathrm{S}-10^{\circ} \mathrm{N}\right)$ in different simulations, overlaid by the corresponding ENSO-forced Walker Circulation variability. During the PI simulation, the center of mean tropical Pacific Walker Circulation (PWC; contours in Fig. 8a) locates in the mid-troposphere (500 hPa) over the central Pacific, with the western edge (shown by zero bold lines) is at around $140^{\circ} \mathrm{E}$. Although the climate mean ZMS during Pliocene (LGM) has similar patterns to PI, obvious differences also exist: the western edge of ZMS over the Pacific show westward and eastward shift to around $130^{\circ} \mathrm{E}$ and $170^{\circ} \mathrm{E}$ during Pliocene and LGM, respectively (Fig. 8b, c). As for the ENSO-driven Walker Circulation, they show positive ZMS anomalies over the Indian Ocean, and negative anomalies roughly across the whole Pacific in these three experiments (shading in Fig. 8), indicating a weakening and eastward shift of the Pacific Walker Circulation. Previous studies (Bayr et al. 2014; Ma and Zhou 2016) suggest that the significant negative ZMS anomaly in the western Pacific can induce anomalous ascending motion. However, because of the movement of climate mean Walker Circulation mentioned above, these maximum negative anomalies over the western Pacific also show relatively shift. In particular, the center of a maximum negative anomaly in PI is at around $140^{\circ} \mathrm{E}$ (shading in Fig. 7a), it shifts westward by $\sim 15^{\circ}$ in Pliocene and eastward by $\sim 25^{\circ}$ in LGM (shading in Fig. $8 \mathrm{~b}$ and c).

To demonstrate the relationship between the shift of Walker Circulation and the changes in ENSO-driven vertical velocity, we show the zonal mean of vertical integrated ZMS and changes in vertical velocity at $700 \mathrm{hPa}$ in Fig. 9. The westward shift of ENSO-driven Walker Circulation does exist in the Pliocene experiment, and the eastward shift 
(a) ENSO W (PI)
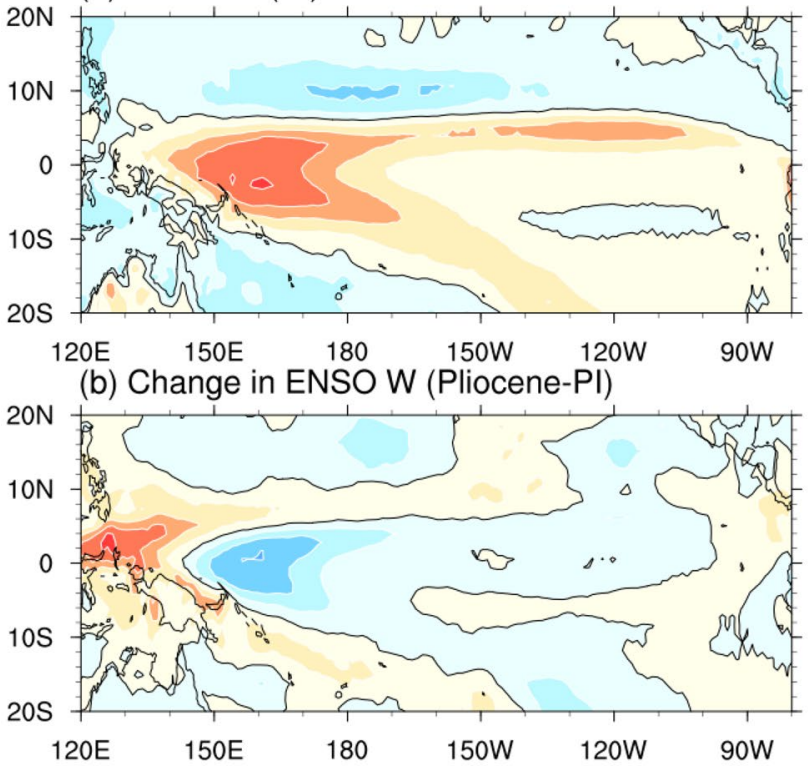

(c) Change in ENSO W (LGM-PI)

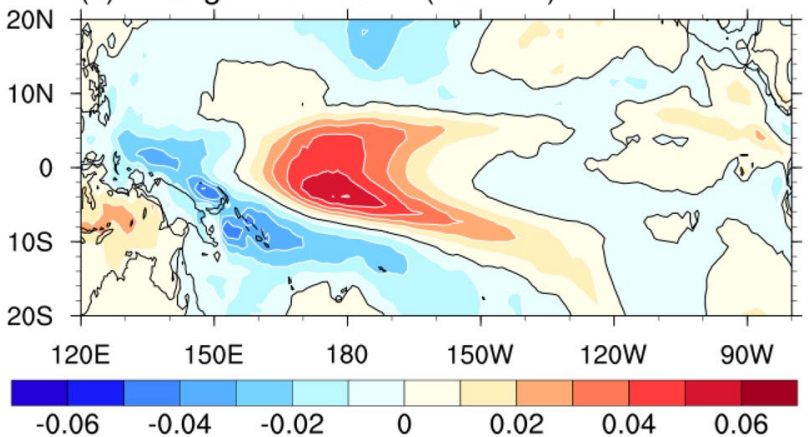

Fig. 7 a The ENSO-driven $700 \mathrm{hPa}$ vertical pressure velocity variability in the PI simulation.[multiplied by -1 , positive (negative) values indicate ascending (descending) motion; unit: $\mathrm{Pa} \mathrm{s} \mathrm{s}^{-1}$. The changes in ENSO vertical velocity for $\mathbf{b}$ Pliocene and $\mathbf{c}$ LGM compare to PI simulation. The solid black curves represent zero lines

occurs in the LGM experiment (Fig. 9a, red vs. blue). Correspondingly, the ENSO-induced ascending motion shows the similar movements controlled by the shift of Walker Circulation, the maximum positive anomaly shifts westward in the Pliocene and eastward in LGM (Fig. 9b, red vs. blue). The differences between the sensitivity experiments and PI simulation in Fig. 9b are further shown in Fig. 9c. In general, the westward shift of Walker Circulation in Pliocene trigger anomalous ascending (descending) motion over the western (central) Pacific, while the opposite patterns are found in the LGM (Fig. 9c). These are consistent with the results in Fig. 7.

Many studies (Tokinaga et al. 2012; Sohn et al. 2016; Chung et al. 2019) show that the changes in zonal SST gradient along the equatorial Indo-Pacific Ocean cause the Walker Circulation anomalies. Indeed, the universal warmer SST in Pliocene (Fig. 10a) and cooler SST in LGM

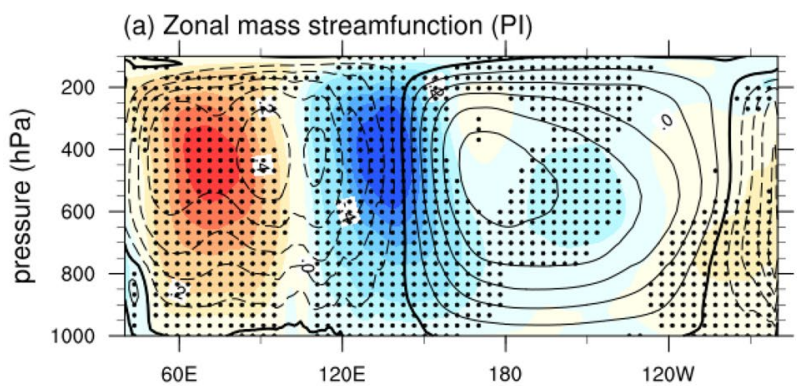

(b) Zonal mass streamfunction (Pliocene)

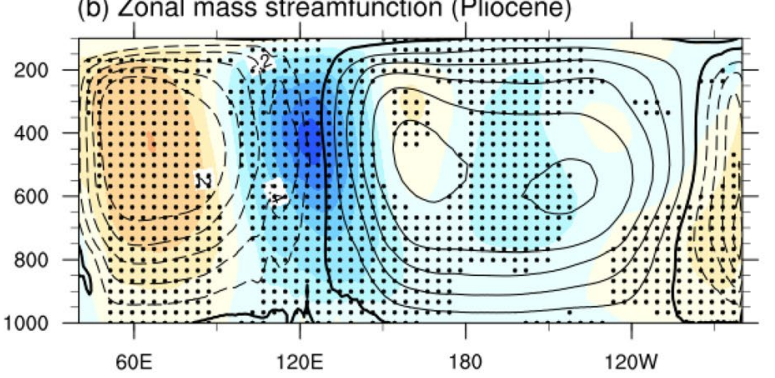

(c) Zonal mass streamfunction (LGM)

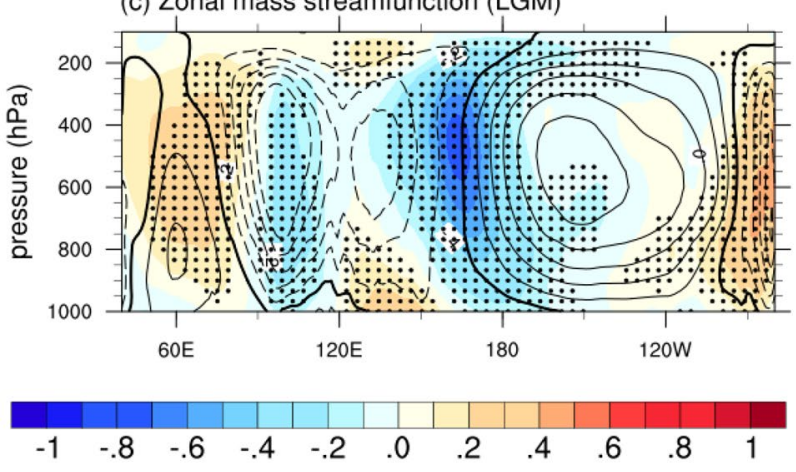

Fig. 8 The climate mean of zonal mass stream function (ZMS, averaged between $10^{\circ} \mathrm{S}-10^{\circ} \mathrm{N}$; contours, unit: $10^{10} \mathrm{~kg} \mathrm{~s}^{-1}$ ) along the equatorial Indo-Pacific for a PI simulation, b Pliocene and c LGM, with the ENSO-driven ZMS variability (shading). The solid black curves represent zero lines. The stippling indicates a statistical significance at the $95 \%$ level by using the Mann-Kendall trend test

(Fig. 10c) are consistent with previous studies (Clark et al. 2009; Burls and Fedorov 2017). Interestingly, our simulations show significant warming (cooling) signals over the tropical Indian Ocean during Pliocene (LGM), where the SLP roughly lower (higher) than in the tropical centraleastern Pacific (Fig. 10b, d), and resulting in an increased (reduced) zonal SLP gradient. As a result, the enhanced (weakened) zonal SST gradient exists in Pliocene (LGM), inducing the anomalous easterly (westerly) winds in the central Pacific at around $170^{\circ} \mathrm{E}$ (vectors in Fig. 10b, c). Note that the winds anomalies are the lower portion of Walker Circulation, also suggesting the strengthening and westward shift (weakening and eastward shift) of Walker Circulation in Pliocene (LGM). 

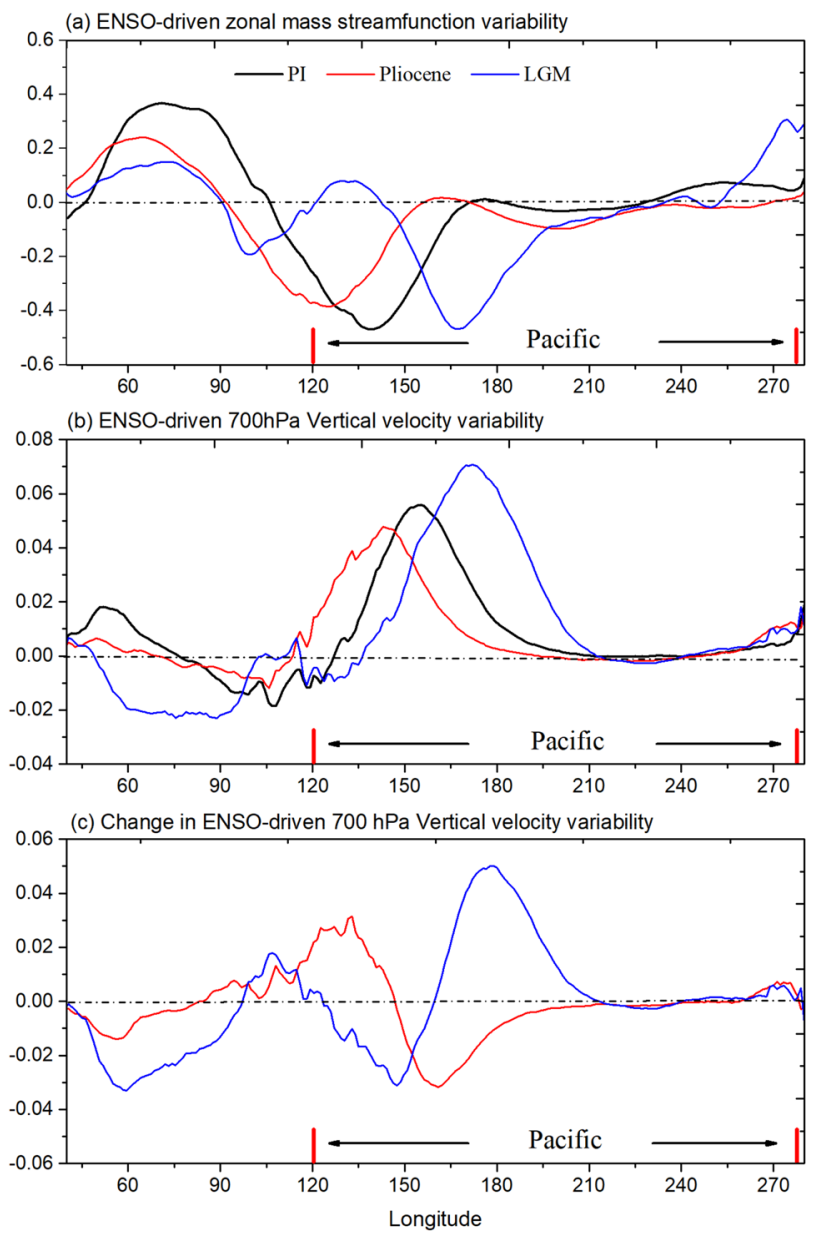

Fig. 9 The meridional average $\left(10^{\circ} \mathrm{S}-10^{\circ} \mathrm{N}\right)$ of a vertical integrated ENSO-driven ZMS (unit: $10^{10} \mathrm{~kg} \mathrm{~s}^{-1}$ ) and the ENSO-driven vertical pressure velocity variability (unit: $\mathrm{Pa} \mathrm{s}^{-1}$ ) at $700 \mathrm{hPa}$ level over equatorial Indian and Pacific Oceans. $\mathbf{c}$ The vertical velocity anomaly relative to PI simulation for sensitive experiments

Overall, the EC-Earth simulations show that the shift of climatological Walker Circulation mainly controls the changes in ENSO-forced vertical velocity variability, and then the changes in ENSO precipitation, which is owing to the changes in zonal SST gradient along the equatorial Indo-Pacific under past warm and cold periods. The changes in the zonal SST gradient might be related to the $\mathrm{CO}_{2}$ concentration. For instance, Luo et al. (2012) suggest that the enhanced tropical Indian Ocean warming favors stronger trade winds in the western Pacific, resulting in stronger east-west Walker circulation. Cane et al. (1997) and Seager et al. (2019) argue that some of the added heat could be diverted away from the cold tongue in response to increasing greenhouse gases (GHGs), resulting from the upwelling and shallower thermocline. Therefore, the eastern Pacific becomes less warm than the West Pacific warm pool, this process can be further amplified by Bjerknes feedbacks. These features can lead to a stronger zonal SST gradient that shoal the thermocline and cause stronger trades. As mentioned above, the major forcing in the two sensitivity experiment for Pliocene and LGM is the $\mathrm{CO}_{2}$ level, the opposite changes in past warm/cold climates suggest that the change in $\mathrm{CO}_{2}$ level may be one of the crucial external forcings in driving the tropical zonal SST gradient in the Pliocene and LGM.

\section{Summary and discussion}

In this study, we investigate the changes in ENSO-driven precipitation variability according to the EC-Earth coupled model simulations for the past warm (Pliocene) and cold (LGM) climates. The main conclusions are summarized as follows.

The simulated ENSO-driven precipitation variability is strengthened over the western Pacific but weakened over the central Pacific during Pliocene. The opposite results exhibit in LGM, showing weakened ENSO precipitation over the western Pacific, but increased over the central Pacific. The corresponding mechanisms of precipitation anomaly are explored based on the decomposed moisture budget equation. The results illustrate that the changes in ENSO precipitation are overwhelmingly controlled by the effect of the dynamic component under different climate conditions, which reflects the circulation anomalies. In more detail, the increased ENSO precipitation during Pliocene is caused by the anomalous ascending variability at the low-level troposphere, which is caused by the strengthened and westward shift of climatological Pacific Walker Circulation. The westward shift of Pacific Walker Circulation favors convergent (divergent) circulation anomalies over western (central) Pacific, and thus results in a positive (negative) contribution to intensify (weaken) the changes in ENSO precipitation. The mechanisms also apply in LGM but with roughly opposite changes: the weakened ENSO precipitation over the western Pacific is caused by the weakened and eastward shift of climatological Pacific Walker Circulation. In this study, the inhomogeneous warming (cooling) over the tropical Indo-Pacific ocean induces a greater (smaller) zonal SST gradient and drives easterly (westerly) wind anomalies over the tropical western-central Pacific, leading to the enhanced (weakened) climate mean Pacific Walker Circulation along with a westward (eastward) shift during Pliocene (LGM).

Our work provides a relatively complete understanding of the changes in ENSO precipitation under past warm and cold climates. We highlight that the thermal gradient over the tropical Indo-Pacific is the key factor to determine the ENSO precipitation through circulation anomalies in response to external forcings. Our results show that warm (cold) climate favors a stronger (weaker) zonal SST gradient over the tropical Indo-Pacific Ocean compared to PI simulation. Rickaby 
(a) Change in SST (Pliocene-PI)

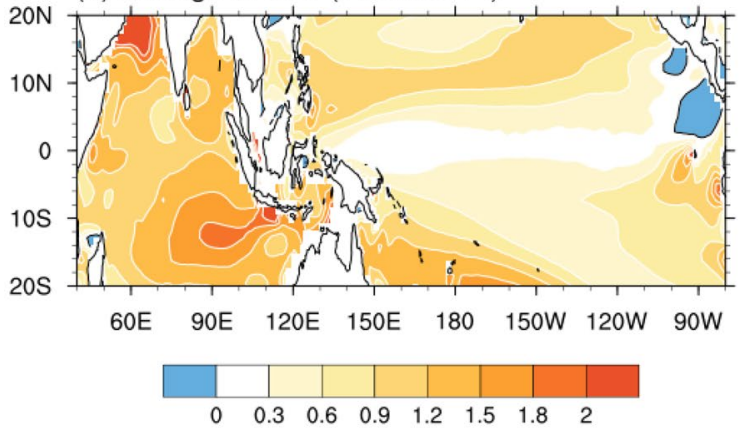

(c) Change in SST (LGM-PI)

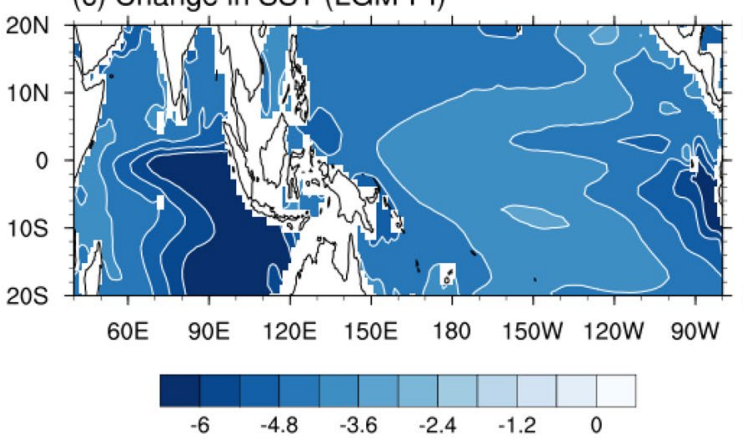

(b) Change in SLP (Pliocene-PI)

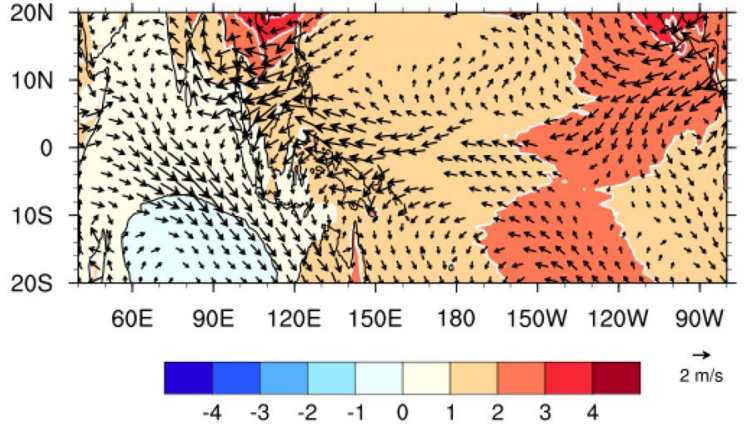

(d) Change in SLP (LGM-PI)

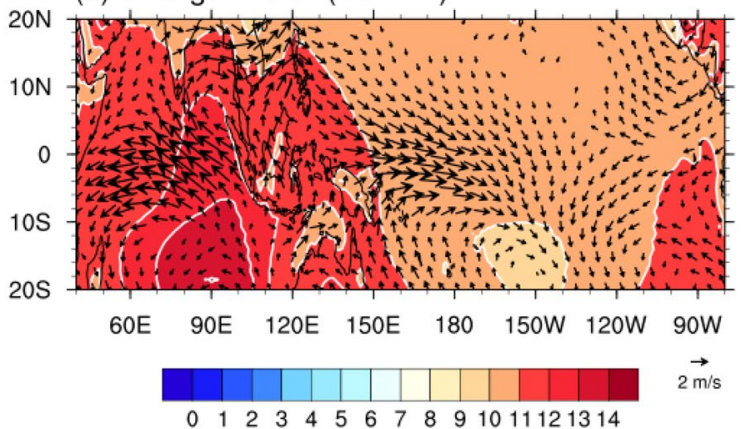

Fig. 10 The simulated changes in climate mean SST (shading in left; unit: K), SLP (shading in right; unit: hPa) and the $850 \mathrm{hPa}$ winds (vectors in right; unit: $\mathrm{m} \mathrm{s}^{-1}$ ) for $\mathbf{a}, \mathbf{b}$ Pliocene and $\mathbf{c}, \mathbf{d}$ LGM compared to PI simulation

and Halloran (2005) provide strong evidence that the eastern equatorial Pacific has a La Niña-like state suggested by the Pliocene paleothermometer, leading to an increase in the zonal SST gradient in the tropics. The recent work by Seager et al. (2019) demonstrates that the anomalous warming over the central-eastern Pacific under global warming in the state-of-the-art models is due to the too-cold cold tongue bias. Their research highlight that the stronger zonal SST gradient in response to rising GHGs. However, some other studies indicate stronger warming signals over the equatorial central-eastern Pacific compared to the western Pacific under global warming (Meehl et al. 2007; Coats and Karnauskas 2017). A "permanent El Niño" in the tropical Pacific is suggested in Pliocene (Molnar and Cane 2002; Fedorov et al. 2006; Scroxton et al. 2011; Watanabe et al. 2011). These studies imply that the reduced zonal SST gradient may occur in a warmer climate. The similar dispute also exist in the LGM cold climate. Koutavas et al. (2002) suggest a persistent El Niño-like pattern exist in the tropical Pacific by using a reconstructed SST record near Galápagos Islands, implying a relaxation of tropical temperature gradients. Ford et al. (2018) further indicate that this reduced SST gradient is caused by the deeper thermocline during LGM in the eastern equatorial Pacific region. In the meantime, there are substantial studies suggest a La Niña-like cooling. Trend and Prell (2002) reconstruct the SST by using a database of 292 planktonic foraminiferal samples, and they find a marked cooling in the central to eastern tropical Pacific, resulting in an increased east-west SST gradient. The earlier SST reconstruction according the $\mathrm{Mg} / \mathrm{Ca}$ and $\delta^{18} \mathrm{O}$ in Pacific also exhibit an increased eastern cooling (Pisias and Rea 1988). Thus, whether the zonal SST gradient in tropics become stronger or weaker remains controversial during past warm and cold climate. Much more works are needed in the future.

The anomalous precipitation changes in tropics also show implications for the teleconnections changes in mid-to-high latitudes (Bonfifils et al. 2015). Accompanied with the shift patterns of ENSO precipitation in the tropics (Fig. 2), the Aleutian low shifts slightly westward (eastward) in the Pliocene (LGM) as shown in Fig. 11a, b. In addition, the ENSOrelated 500-hPa geopotential height (HGT) anomalies over the North Pacific and North America indicate the PacificNorth American (PNA) teleconnection pattern (Barnston and Livezey 1987) response. This teleconnection pattern changes show movements in different experiments similar to those of SLP [i.e., westward (eastward) for the Pliocene (LGM); Fig. 11c, d], especially during the boreal wintertime (not shown). Zhou et al. (2014) indicate that these teleconnections anomalies can affect the surface temperature and precipitation. Their results suggest that the eastward movement of the SLP over North Pacific causes Alaska cooling, Japan and the South China Sea warming, and also induce 
(a) SLP (Pliocene)
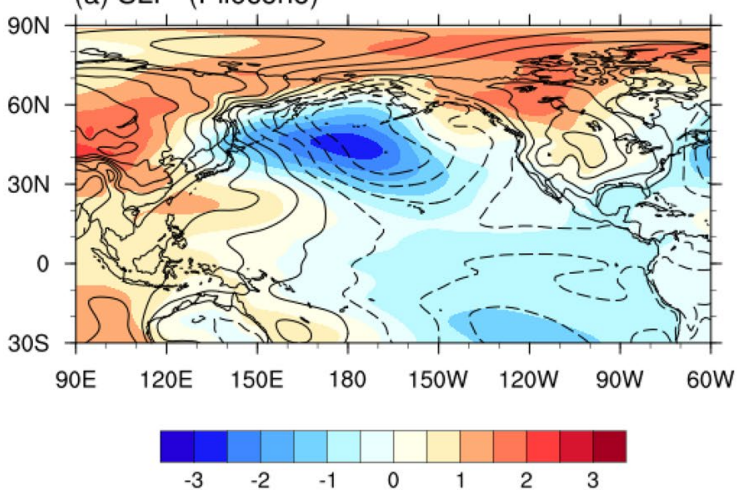

(c) HGT 500hPa (Pliocene)

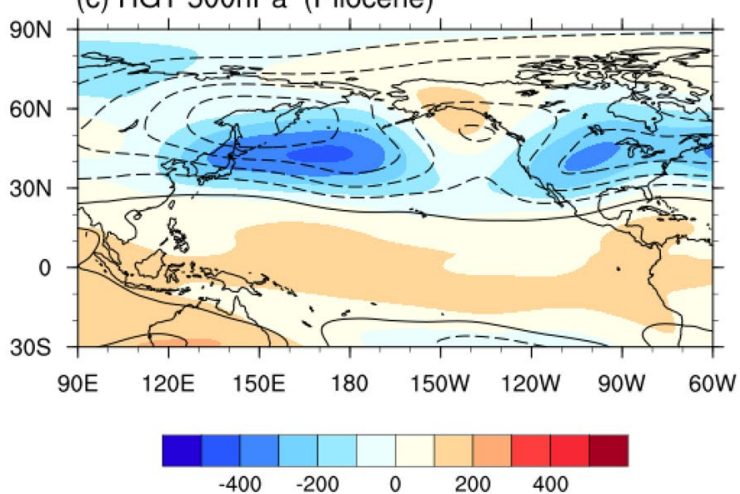

(b) SLP (LGM)

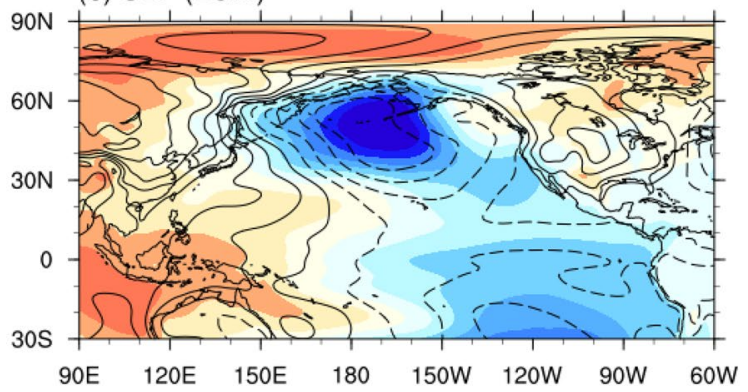

(d) HGT $500 \mathrm{hPa}$ (LGM)
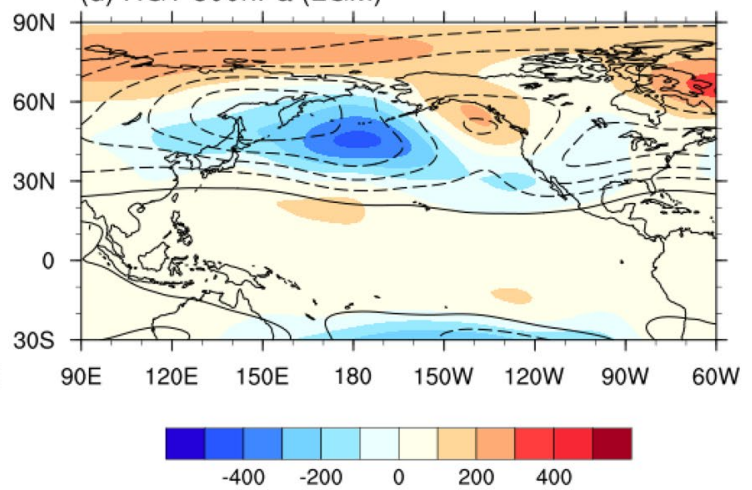

Fig. 11 The ENSO-induced SLP (hPa) and 500-hPa geopotential height (m) variability for a, c Pliocene (shading) and b, d LGM (shading) in Pacific overlaid with PI simulation [contours, solid (dashed) lines are positive (negative) values]

increased rainfall over U.S. West Coast. Thus, the impact of the teleconnections in mid-to-high latitudes, affected by changes in ENSO precipitation, on nearby continents need further study in the future work.

As this study focuses on the anomalous climate in tropics, the relationship between extra-tropical regions and tropics is not discussed thoroughly. In fact, the Walker Circulation can be also indirectly influenced by the other factors in subtropics, e.g. western North Pacific (WNP) monsoon (Zhang and Li 2017), land-sea temperature gradient (Yim et al. 2017). Focusing on the high latitude, the extent and volume of sea ice and land ice play a crucial role in low latitude climate change. Lu et al. (2016) indicate that the cooling in North Atlantic and Pacific, induced by the retreat of Laurentide ice-sheet, can impact the ENSO variability through the jet stream in the Northern Hemisphere. In this study, we focus on the zonal SST gradient under different $\mathrm{CO}_{2}$ forcings. On the other hand, Liu et al. (2005) have investigated the meridional SST gradient in response to increased atmospheric $\mathrm{CO}_{2}$ concentration and found a robust equatorial warming relative to the subtropics under global warming. This meridional SST gradient can further affect the atmospheric circulation and tropical physics. However, in our simulation, the evident trade wind response and the slight SST meridional gradient during the LGM suggest this ocean response mechanism to external forcings may not be dominant, especially in a cold climate state. These comprehensive remote forcing mechanisms in mid to high latitude under different climate states are beyond the scope of this study and will be investigated in future work.

For the warm climate state, indeed the simulated equatorial warming is a dominant/consistent signal as a response to the global warming compared to the zonal contrast change of SST. However, it should be noted that there are many differences in our model set-up compared to the $\mathrm{CO}_{2}$ forcing experiments in Liu et al. (2005) and Pliocene simulation. In fact, the reduced meridional SST gradient in Pliocene has been validated in observations and other model simulations (Yan et al. 2011; Contoux et al. 2012; Chandler et al. 2013). Many studies have tried to improve the understanding the SST pattern formation and maintenance in the pre-Quaternary through high latitude (thermohaline circulation and icealbedo feedback; e.g., Crowley 1996; Robinson 2009; Steph et al. 2010; Etourneau et al. 2010) and tropical perspectives (ocean upwelling and air-sea interaction; e.g., Philander and Fedorov 2003; Fedorov et al. 2006; Ravelo 2010). The reduced meridional SST gradient is a robust phenomenon in Pliocene compared with PI, although the mechanisms 
are still under debate. This SST pattern results in weaker Hadley circulation (not shown). Like many studies, without sensitivity experiments we can not answer which mechanism is responsible for the reduced SST meridional gradient in Pliocene, and it is beyond the scope of this study. Further effort in improving the understanding of the control factors for mid-Pliocene sea surface condition will be in our future work.

Additionally, Lacagnina and Selten (2014) indicate that the EC-Earth shows the large cloud biases in the tropics, resulting in underestimates the total cloud cover. Burls and Fedorov (2014) demonstrate that the meridional cloud albedo plays an important role in sustaining the changes in meridional and zonal SST gradients by using a range of hypothetical modified clouds albedo experiments, leading to anomalous overturning circulation at low latitude. Thus, these cloud biases in EC-Earth might influence the tropical circulation anomalies, and we should examine the role of cloud cover, especially the change in cloud albedo, through sensitivity experiments in the future work. Note also that our studies are based on the simulations with an individual model EC-Earth, and the results could be model-dependent. Especially, it is well-known that simulation of ENSO has large diversity among different models. A series of sensitivity experiments in response to different external forcing and their direct or indirect influences over the tropics are further needed. Particularly, we need to compare our results with other PMIP simulations.

Acknowledgements Open access funding provided by Stockholm University. This study acknowledges the Swedish Research Council (Vetenskapsrådet, grant no. 2013-06476 and 2017-04232), National Natural Science Foundation of China (Grant Nos. 41530531, 41675092, 41705053, 41575082, 41575074), the National Key R\&D Program of China (Grant No. 2017YFC1502303). Data analysis is performed on the Swedish National Infrastructure for Computing (SNIC) at the National Supercomputer Centre (NSC). We also gratefully acknowledge financial support from the China Scholarship Council.

Open Access This article is licensed under a Creative Commons Attribution 4.0 International License, which permits use, sharing, adaptation, distribution and reproduction in any medium or format, as long as you give appropriate credit to the original author(s) and the source, provide a link to the Creative Commons licence, and indicate if changes were made. The images or other third party material in this article are included in the article's Creative Commons licence, unless indicated otherwise in a credit line to the material. If material is not included in the article's Creative Commons licence and your intended use is not permitted by statutory regulation or exceeds the permitted use, you will need to obtain permission directly from the copyright holder. To view a copy of this licence, visit http://creativecommons.org/licenses/by/4.0/.

\section{References}

Adler RF, Huffman GJ, Chang A, Ferraro R, Xie PP, Janowiak J, Rudolf B, Schneider U, Curtis S, Bolvin D, Gruber A (2003) The version-2 global precipitation climatology project (GPCP) monthly precipitation analysis (1979-present). J Hydrometeorol 4(6): 1147-1167

An SI, Timmermann A, Bejarano L, Jin FF, Justino F, Liu Z, Tudhope AW (2004) Modeling evidence for enhanced El Niño-Southern Oscillation amplitude during the last glacial maximum. Paleoceanography 19(4):PA4009

Adames ÁF, Wallace JM (2017) On the tropical atmospheric signature of El Niño. J Atmos Sci 74(6):1923-1939

Bayr T, Dommenget D, Martin T, Power SB (2014) The eastward shift of the Walker Circulation in response to global warming and its relationship to ENSO variability. Clim Dyn 43(9-10):2747-2763

Balsamo G, Beljaars A, Scipal K, Viterbo P, van den Hurk B, Hirschi M, Betts AK (2009) A revised hydrology for the ECMWF model: Verification from field site to terrestrial water storage and impact in the Integrated Forecast System. J Hydrometeorol 10(3):623-643

Bjerknes JA (1969) Atmospheric teleconnections from the equatorial pacific1. Mon Weather Rev 97(3):163-172

Bosmans JHC, Drijfhout SS, Tuenter E, Lourens LJ, Hilgen FJ, Weber SL (2012) Monsoonal response to midholocene orbital forcing in a high resolution GCM. Clim Past 8:723-740. https://doi. org/10.5194/cp-8-723-2012

Bonham SG, Haywood AM, Lunt DJ, Collins M, Salzmann U (2009) El Niño-Southern Oscillation, Pliocene climate and equifinality. Phil Trans R Soc A 367:127-156

Barnston AG, Livezey RE (1987) Classification, seasonality andpersistence of low-frequency atmospheric circulation patterns. Mon Weather Rev 115:1083-1126

Bonfifils CJW, Santer BD, Phillips TJ, Marvel K, Leung LR, Doutriaux C, Capotondi A (2015) Relative contributions of meanstate shifts and ENSO-driven variability to precipitation changes in a warming climate. J Clim 28(9997-10):013. https://doi. org/10.1175/JCLI-D-15-0341.1

Burls NJ, Fedorov AV (2017) Wetter subtropics in a warmer world: contrasting past and future hydrological cycles. Proc Natl Acad Sci 114(49):12888-12893

Burls NJ, Fedorov AV (2014) Simulating Pliocene warmth and a permanent El Niño-like state: the role of cloud albedo. Paleoceanography 29(10):893-910

Cai W, Van Rensch P, Cowan T, Sullivan A (2010) Asymmetry in ENSO teleconnection with regional rainfall, its multidecadal variability, and impact. J Clim 23(18):4944-4955

Cai W et al (2015) ENSO and greenhouse warming. Nat Clim Change 5:849-859. https://doi.org/10.1038/nclimate2743

Capotondi A, Ham YG, Wittenberg A, Kug JS (2015) Climate model biases and El Niño Southern Oscillation (ENSO) simulation. US CLIVAR Var 13(1):21-25

Cane MA et al (1997) Twentieth century sea surface temperature trends. Science 275:957-960

Chandler MA, Sohl LE, Jonas JA et al (2013) Simulations of the MidPliocene warm period using two versions of the NASA-GISS ModelE2-R coupled model

Chen L, Wang L, Li T, Liu J (2019) Drivers of reduced ENSO variability in mid-Holocene in a coupled model. Clim Dyn 52(9-10):5999-6014

Chung CT, Power SB (2014) Precipitation response to La Niña and global warming in the Indo-Pacific. Clim Dyn 43(12):3293-3307 
Chung CT, Power SB, Arblaster JM, Rashid HA, Roff GL (2014) Nonlinear precipitation response to El Niño and global warming in the Indo-Pacific. Clim Dyn 42(7-8):1837-1856

Chung ES, Timmermann A, Soden BJ, Ha KJ, Shi L, John VO (2019) Reconciling opposing Walker circulation trends in observations and model projections. Nat Clim Change 9(5):405

Chang EKM, Lee S, Swanson KL (2002) Storm track dynamics. J Clim $15: 2163-2183$

Clement AC, Seager R, Cane MA, Zebiak SE (1996) An ocean dynamical thermostat. J Clim 9(9):2190-2196

Clark PU, Dyke AS, Shakun JD et al (2009) The last glacial maximum. Science 325(5941):710-714

Crowley TJ (1996) Pliocene climates: the nature of the problem. Mar Micropaleontol 27(1-4):3-12

Collins $M$ et al (2010) The impact of global warming on the tropical Pacific Ocean and El Niño. Nat. Geosci. 3:391-397. https://doi. org/10.1038/ngeo868

Collins M, Knutti R, Arblaster J, Dufresne J, Fichefet T, Friedlingstein P, Gao X, Gutowski W, Johns T, Krinner G, Shongwe M, Tebaldi C, Weaver A, Wehner M (2013) Longterm climate change: projections, commitments and irreversibility. In: Working Group 1 Contribution to the IPCC Fifth Assessment Report-Climate Change: The Physical Science Basis, pp 1029-1136

Coats S, Karnauskas KB (2017) Are simulated and observed twentieth century tropical Pacific sea surface temperature trends significant relative to internal variability? Geophys Res Lett 44(19):9928-9937

Compo GP, Whitaker JS, Sardeshmukh PD, Matsui N, Allan RJ, Yin X, Gleason BE, Vose RS, Rutledge G, Bessemoulin P, Brönnimann S (2011) The twentieth century reanalysis project. Q J R Meteorol Soc 137(654):1-28

Contoux C, Ramstein G, Jost A (2012) Modelling the mid-Pliocene Warm Period climate with the IPSL coupled model and its atmospheric component LMDZ5A. Geosci Model Dev 5(3):903

Dai A, Wigley TML (2000) Global patterns of ENSO-induced precipitation. Geophys Res Lett 27(9):1283-1286

Dekens PS, Ravelo AC, McCarthy MD (2007) Warm upwelling regions in the Pliocene warm period. Paleoceanography 22:PA3211. https://doi.org/10.1029/2006PA001394

Deser C, Alexander MA, Xie SP, Phillips AS (2010) Sea surface temperature variability: 452 patterns and mechanisms. Ann Rev Mar Sci 2:115-143

Dowsett HJ (2007) The PRISM palaeoclimate reconstruction and Pliocene sea-surface temperature. Deep-time perspectives on climate change: marrying the signal from computer models and biological proxies. The Micropalaeontological Society, Special Publication. The Geological Society, London, UK, pp 459-480

Dowsett HJ, Robinson MM (2009) Mid-Pliocene equatorial Pacific sea surface temperature reconstruction: a multi-proxy perspective. Philos Trans R Soc A Math Phys Eng Sci 367(1886):109-125

Dowsett HJ, Robinson MM, Haywood AM, Hill DJ, Dolan AM, Stoll DK, Chan W-L, Abe-Ouchi A, Chandler MA, Rosenbloom NA, Otto-Bliesner BL, Bragg FJ, Lunt DJ, Foley KM, Riesselman CR (2012) An assessment of confidence in Pliocene global seasurface temperature. Nat Clim Change 2:365-371

Dowsett H, Dolan A, Rowley D, Moucha R, Forte AM, Mitrovica JX, Pound M, Salzmann U, Robinson M, Chandler M, Foley K (2016) The PRISM4 (mid-Piacenzian) paleoenvironmental reconstruction. Clim Past 12:1519-1538

Etourneau J, Schneider R, Blanz T, Martinez P (2010) Intensification of the Walker and Hadley atmospheric circulations during the Pliocene-Pleistocene climate transition. Earth Planet Sci Lett 297(1-2): 103-110

Fedorov AV, Brierley CM, Lawrence KT, Liu Z, Dekens PS, Ravelo AC (2013) Patterns and mechanisms of early Pliocene warmth. Nature 496(7443):43
Fedorov AV, Dekens PS, McCarthy M, Ravelo AC, DeMenocal PB, Barreiro M, Pacanowski RC, Philander SG (2006) The Pliocene paradox (mechanisms for a permanent El Niño). Science 312(5779):1485-1489

Flato G, Marotzke J, Abiodun B., Braconnot P, Chou S, Collins W, Cox P, Driouech F, Emori S, Eyring V, Forest C, Gleckler P, Guilyardi E, Jakob C, Katssov V, Reason C, Rummukainen M (2013) Evaluation of climate models. In: Climate change 2013: the physical science basis. Contribution of Working Group I to the Fifth Assessment Report of the Intergovernmental Panel on Climate Change. Cambridge University Press, Cambridge, United Kingdom and New York, pp 743-866

Ford HL, McChesney CL, Hertzberg JE, McManus JF (2018) A deep eastern equatorial Pacific thermocline during the Last Glacial Maximum. Geophys Res Lett 45(21):11-806

Galeotti S, Von der Heydt A, Huber M, Bice D, Dijkstra H, Jilbert T, Lanci L, Reichart GJ (2010) Evidence for active El Niño Southern Oscillation variability in the Late Miocene greenhouse climate. Geology 38(5):419-422

Haywood A, Dowsett H, Dolan A, Rowley D, Abe-Ouchi A, OttoBliesner B, Chandler M, Hunter S, Lunt D, Pound M, Salzmann U (2016) The Pliocene model intercomparison project (PlioMIP) phase 2: scientific objectives and experimental design. Clim Past 12(3):663-675

Hazeleger W, Wang X, Severijns C, Ştefănescu S, Bintanja R, Sterl A, Wyser K, Semmler T, Yang S, Van den Hurk B, Van Noije T (2012) EC-Earth V2. 2: description and validation of a new seamless earth system prediction model. Clim Dyn 39(11):2611-2629

Haywood AM, Valdes PJ, Peck VL (2007) A permanent El Nĩno-like state during the Pliocene? Paleoceanography 22:PA1213. https ://doi.org/10.1029/2006PA001323

Hazeleger W, Severijns C, Semmler T, Ştefănescu S, Yang S, Wang X, Wyser K, Dutra E, Baldasano JM, Bintanja R, Bougeault P (2010) EC-Earth: a seamless earth-system prediction approach in action. Bull Am Meteor Soc 91(10):1357-1364

Han Z, Su T, Huang B, Feng T, Qu S, Feng G (2019) Changes in global monsoon precipitation and the related dynamic and thermodynamic mechanisms in recent decades. Int J Climatol 39(3):1490-1503

Held IM, Soden BJ (2006) Robust responses of the hydrological cycle to global warming. J Clim 19:5686-5699

He J, Soden BJ (2015) Anthropogenic weakening of the tropical circulation: the relative roles of direct $\mathrm{CO} 2$ forcing and sea surface temperature change. J Clim 28:8728-8742. https://doi. org/10.1175/JCLI-D-15-0205.1

Herbert TD, Lawrence KT, Tzanova A, Peterson LC, Caballero-Gill R, Kelly CS (2016) Late Miocene global cooling and the rise of modern ecosystems. Nat Geosci 9(11):843

Huang P, Xie SP (2015) Mechanisms of change in ENSO-induced tropical Pacific rainfall variability in a warming climate. Nat Geosci 8(12):922

Huang P (2016) Time-varying response of ENSO-induced tropical Pacific rainfall to global warming in CMIP5 models. Part I: multimodel ensemble results. J Clim 29(16):5763-5778

Jochum M, Fox-Kemper B, Molnar PH, Shields C (2009) Differences in the Indonesian seaway in a coupled climate model and their relevance to Pliocene climate and El Nino. Paleoceanography. https://doi.org/10.1029/2008PA001678

Kiladis GN, Diaz HF (1989) Global climatic anomalies associated with extremes in the Southern Oscillation. J Clim 2(9):1069-1090

Koutavas A, Joanides S (2012) El Niño-Southern oscillation extrema in the holocene and last glacial maximum. Paleoceanography 27(4):PA4208

Koutavas A, Lynch-Stieglitz J, Marchitto TM, Sachs JP (2002) El Nino-like pattern in ice age tropical Pacific sea surface temperature. Science 297(5579):226-230 
Lacagnina C, Selten F (2014) Evaluation of clouds and radiative fluxes in the EC-Earth general circulation model. Clim Dyn 43(9-10):2777-2796

Leduc G, Vidal L, Cartapanis O, Bard E (2009) Modes of eastern equatorial Pacific thermocline variability: Implications for ENSO dynamics over the last glacial period. Paleoceanography 24(3):PA3202

Lea DW, Pak DK, Spero HJ (2000) Climate impact of late Quaternary equatorial Pacific sea surface temperature variations. Science 289(5485):1719-1724

Liu WT, Katsaros KB, Businger JA (1979) Bulk parameterization of air-sea exchanges of heat and water vapor including the molecular constraints at the interface. J Atmos Sci 36:1722-1735

Liu Z, Vavrus S, He F, Wen N, Zhong Y (2005) Rethinking tropical ocean response to global warming: the enhanced equatorial warming. J Clim 18(22):4684-4700

Lu Z, Liu Z, Zhu J (2016) Abrupt intensification of ENSO forced by deglacial ice-sheet retreat in CCSM3. Clim Dyn 46(5-6):1877-1891

Luo JJ, Sasaki W, Masumoto Y (2012) Indian Ocean warming modulates Pacific climate change. Proc Natl Acad Sci 109(46):18701-18706

Ma J, Xie S-P (2012) Regional patterns of sea surface temperature change: a source of uncertainty in future projections of precipitation and atmospheric circulation. J Clim 26:2482-2501. https:// doi.org/10.1175/JCLI-D-12-00283.1

Madec G (2008) The Nemo team (2008) NEMO ocean engine. Note du Pôle de modélisation Institut. Pierre-Simon Laplace (IPSL), Paris

Martínez-Botí MA, Foster GL, Chalk TB, Rohling EJ, Sexton PF, Lunt DJ, Pancost RD, Badger MPS, Schmidt DN (2015) Plio-Pleistocene climate sensitivity evaluated using high-resolution $\mathrm{CO} 2$ records. Nature 518(7537):49

Ma S, Zhou T (2016) Robust strengthening and westward shift of the tropical Pacific Walker circulation during 1979-2012: a comparison of 7 sets of reanalysis data and 26 CMIP5 models. J Clim 29(9):3097-3118

McPhaden MJ, Zebiak SE, Glantz MH (2006) ENSO as an integrating concept in earth science. Science 314:1740-1745

Meehl GA, Stocker TF, Collins WD, Friedlingstein P, Gaye T, Gregory JM, Kitoh A, Knutti R, Murphy JM, Noda A, Raper SC (2007) Global climate projections. Cambridge University Press, Cambridge

Molnar P, Cane MA (2002) El Niño's tropical climate and teleconnections as a blueprint for pre-Ice Age climates. Paleoceanography 17(2):11-21

Otto-Bliesner BL, Brady EC, Shin SI, Liu Z, Shields C (2003) Modeling El Niño and its tropical teleconnections during the last glacial-interglacial cycle. Geophys Res Lett 30(23):2198

Pausata FS, Zhang Q, Muschitiello F, Lu Z, Chafik L, Niedermeyer EM, Stager JC, Cobb KM, Liu Z (2017) Greening of the Sahara suppressed ENSO activity during the mid-Holocene. Nat Commun 8:16020

Peng D, Zhou T (2017) Why was the arid and semiarid northwest China getting wetter in the recent decades? J Geophys Res Atmos 122(17):9060-9075

Peltier WR (2004) Global glacial isostasy and the surface of the ice-age Earth: the ICE-5G (VM2) model and GRACE. Annu Rev Earth Planet Sci 32:111-149

Philander SG (1990) El Niño and the Southern Oscillation. Academic Press, New York

Ravelo AC, Andreasen DH, Lyle M, Olivarez A, Wara MW (2004) Regional climate shifts caused by gradual global cooling in the Pliocene epoch. Nature 429:263-267

Philander SG, Fedorov AV (2003) Role of tropics in changing the response to Milankovich forcing some three million years ago. Paleoceanography $18(2)$
Pisias NG, Rea DK (1988) Late Pleistocene paleoclimatology of the central equatorial Pacific: Sea surface response to the southeast trade winds. Paleoceanography 3(1):21-37

Power S, Delage F, Chung C, Kociuba G, Keay K (2013) Robust twenty-first-century projections of El Niño and related precipitation variability. Nature 502:541-545. https://doi.org/10.1038/ nature 12580

Power SB, Kociuba G (2011) What caused the observed twentieth-century weakening of the Walker circulation? J Clim 24:6501-6514

Raymo ME, Grant B, Horowitz M, Rau GH (1996) Mid-Pliocene warmth: stronger greenhouse and stronger conveyor. Mari Micropaleontol 27:313-326

Rasmusson EM, Carpenter TH (1982) Variations in tropical sea surface temperature and surface wind fields associated with the Southern Oscillation/El Niño. Mon Weather Rev 110(5):354-384

Ravelo AC, Andreasen DH, Lyle M, Lyle AO, Wara MW (2004) Regional climate shifts caused by gradual global cooling in the Pliocene epoch. Nature 429(6989):263

Ravelo AC (2010) Warmth and glaciation. Nat Geosci 3(10):672-674

Rayner NA, Parker DE, Horton EB, Folland CK, Alexander LV, Rowell DP (2003) Global analyses of sea surface temperature, sea ice, and night marine air temperature since the late nineteenth century. J Geophys Res Atmos 108(D14):1063-1082

Rickaby RE, Halloran P (2005) Cool La Niña during the warmth of the Pliocene? Science 307(5717):1948-1952

Robinson MM, Dowsett HJ, Chandler MA (2008) Pliocene role in assessing future climate impacts. Eos Trans Am Geophys Union 89(49):501-502

Robinson MM (2009) New quantitative evidence of extreme warmth in the Pliocene Arctic. Stratigraphy 6(4):265

Sadekov AY, Ganeshram R, Pichevin L, Berdin R, McClymont E, Elderfield H, Tudhope AW (2013) Palaeoclimate reconstructions reveal a strong link between El Nino-Southern Oscillation and Tropical Pacific mean state. Nat Commun 4:2692

Schwendike J, Govekar P, Reeder MJ, Wardle R, Berry GJ, Jakob C (2014) Local partitioning of the overturning circulation in the tropics and the connection to the Hadley and Walker circulations. J Geophys Res 119:1322-1339. https://doi. org/10.1002/2013JD020742

Scroxton N, Bonham SG, Rickaby REM, Lawrence SHF, Hermoso M, Haywood AM (2011) Persistent El Nino-Southern Oscillation variation during the Pliocene Epoch. Paleoceanography 26:2215. https://doi.org/10.1029/2010PA002097

Seager R, Vecchi GA (2010) Greenhouse warming and the 21st century hydroclimate of southwestern North America. Proc Natl Acad Sci USA 107(50):21277-21282. https://doi.org/10.1073/ pnas.0910856107

Seager R, Naik N, Vecchi GA (2010) Thermodynamic and dynamic mechanisms for large-scale changes in the hydrological cycle in response to global warming. J Clim 23(17):4651-4668

Seager R, Neelin D, Simpson I et al (2014) Dynamical and thermodynamical causes of large-scale changes in the hydrological cycle over North America in response to global warming. J Clim 27(20):7921-7948

Seager R, Naik N, Vogel L (2012) Does global warming cause intensified interannual hydroclimate variability? J Clim 25(9):3355-3372

Seager R, Cane M, Henderson N, Lee DE, Abernathey R, Zhang H (2019) Strengthening tropical Pacific zonal sea surface temperature gradient consistent with rising greenhouse gases. Nat Clim Change 9(7):517

Shi W, Xiao Z, Ai Y (2018) The behavior of deep convective clouds over the warm pool and connection to the Walker circulation. Sci China Earth Sci 61(11):1605-1621

Sterl A, Bintanja R, Brodeau L et al (2012) A look at the ocean in the EC-Earth climate model. Clim Dyn 39(11):2631-2657 
Steph S, Tiedemann R, Prange M, Groeneveld J, Schulz M, Timmermann A, Nürnberg D, Rühlemann C, Saukel C, Haug GH (2010) Early Pliocene increase in thermohaline overturning: a precondition for the development of the modern equatorial Pacific cold tongue. Paleoceanography 25(2):PA2202

Sohn BJ, Lee S, Chung ES, Song HJ (2016) The role of the dry static stability for the recent change in the Pacific Walker circulation. J Clim 29(8):2765-2779

Sun W, Wang B, Zhang Q, Pausata FS, Chen D, Lu G, Yan M, Ning L, Liu J (2019) Northern Hemisphere land monsoon precipitation increased by the Green Sahara during mid-Holocene. Geophys Res Lett 46(16):9870-9879

Tokinaga H, Xie SP, Deser C, Kosaka Y, Okumura YM (2012) Slowdown of the Walker circulation driven by tropical Indo-Pacific warming. Nature 491(7424):439

Trend-Staid M, Prell WL (2002) Sea surface temperature at the Last Glacial Maximum: a reconstruction using the modern analog technique. Paleoceanography 17(4):17-21

Valcke S (2006) OASIS3 User Guide (prism 2-5) Technical Report TR. CMGC/06/73, CERFACS, Toulouse, France

Vancoppenolle M, Fichefet T, Goosse H, Bouillon S, Madec G, Maqueda MAM (2009) Simulating the mass balance and salinity of Arctic and Antarctic Sea Ice. 1. Model description and validation. Ocean Model 27(1-2):33-53

Vecchi GA, Wittenberg AT (2010) El Niño and our future climate: Where do we stand? Wiley Interdiscip. Rev Clim Change 1:260-270. https://doi.org/10.1002/wcc.33

Vecchi GA et al (2006) Weakening of tropical Pacific atmospheric circulation due to anthropogenic forcing. Nature 441:73-76

Vecchi GA, Soden BJ (2007) Global warming and the weakening of the tropical circulation. J Clim 20:4316-4340

Von der Heydt AS, Nnafie A, Dijkstra HA (2011) Cold tongue/Warm pool and ENSO dynamics in the Pliocene. Clim Past 7:903-915

Watanabe T, Suzuki A, Minobe S, Kawashima T, Kameo K, Minoshima K, Aguilar YM, Wani R, Kawahata H, Sowa K, Nagai T (2011)
Permanent El Niño during the Pliocene warm period not supported by coral evidence. Nature 471(7337):209

Wara MW, Ravelo AC, Delaney ML (2005) Permanent El Niñolike conditions during the Pliocene warm period. Science 309(5735):758-761

Yan Q, Zhang ZS, Wang HJ et al (2011) Simulation of sea surface temperature changes in the Middle Pliocene warm period and comparison with reconstructions. Chin Sci Bull 56(9):890

Yim BY, Yeh SW, Song HJ et al (2017) Land-sea thermal contrast determines the trend of Walker circulation simulated in atmospheric general circulation models. Geophys Res Lett 44

Yu B, Zwiers FW, Boer GJ, Ting MF (2012) Structure and variances of equatorial zonal circulation in a multimodel ensemble. Clim Dyn 39:2403-2419. https://doi.org/10.1007/s00382-012-1372-6

Yu L (2007) Global variations in oceanic evaporation (1958-2005): the role of the changing wind speed. J Clim 20(21):5376-5390

Zhang L, Li T (2017) Relative roles of differential SST warming, uniform SST warming and land surface warming in determining the Walker circulation changes under global warming. Clim Dyn 48(3-4):987-997

Zhang X, Lohmann G, Knorr G et al (2013) Different ocean states and transient characteristics in Last Glacial Maximum simulations and implications for deglaciation. Clim Past 9(5):2319-2333

Zheng J, Zhang Q, Li Q, Zhang Q, Cai M (2019) Contribution of sea ice albedo and insulation effects to Arctic amplification in the EC-Earth Pliocene simulation. Clim Past 15(1):291-305

Zhou ZQ, Xie SP, Zheng XT et al (2014) Global Warming-Induced Changes in El Niño Teleconnections over the North Pacific and North America. J Clim 27(24):9050-9064

Publisher's Note Springer Nature remains neutral with regard to jurisdictional claims in published maps and institutional affiliations. 